\title{
SPATIAL AND TEMPORAL VARIATIONS IN THE GROWTH AND PHOTOSYNTHESIS OF SUBMERGED MACROPHYTES IN SONGKHLA LAGOON
}

\author{
SinUtoK, S. ${ }^{1,2}$ - PRAMNEECHOTE, P. $.^{2,3}-$ PrATHEP, A. ${ }^{4}-$ CHOTIKARN, P. ${ }^{1,2,3^{*}}$ \\ ${ }^{1}$ Faculty of Environmental Management, Prince of Songkla University, Hat Yai, Thailand \\ ${ }^{2}$ Coastal Oceanography and Climate Change Research Center, Prince of Songkla University, \\ Hat Yai, Thailand \\ ${ }^{3}$ Marine and Coastal Resources Institute, Faculty of Environmental Management, Prince of \\ Songkla University, Hat Yai, Thailand \\ ${ }^{4}$ Seaweed and Seagrass Research Unit, Division of Biological Science, Faculty of Science, \\ Prince of Songkla University, Hat Yai, Thailand \\ *Corresponding author \\ e-mail: ponlachart.c@psu.ac.th; phone: +66-74-282-335
}

(Received $18^{\text {th }}$ May 2021; accepted $12^{\text {th }}$ Aug 2021)

\begin{abstract}
Increases in organic matter and temperature are major threats to benthic vegetation survival in the Songkhla Lagoon in Southern Thailand, leading to a loss of ecosystem functions and altered biodiversity. This project aimed to investigate the spatial and temporal variations in photosynthesis, growth, and carbon capture potential of submerged macrophytes in Songkhla Lagoon, including potential inhibitory effects of macrophytes on phytoplankton bloom. Percentage cover, photosynthetic performance, morphology and organic content of submerged macrophytes were investigated in situ bimonthly for a year. Environmental parameters such as organic matter content and carbon and nitrogen contents in sediment, nutrients, water temperature, and light were assessed. Free floating macrophytes, submerged macrophytes and macroalgae were observed from May 2017 to May 2018. CCA indicates that the main factors influencing submerged macrophytes were chlorophyll $a$ concentration and dissolved oxygen concentration in the water, depth, organic carbon in sediment, and phosphate concentration in water. This project suggests that the relationship between environmental parameters and composition of macrophytes can be a helpful tool for predicting ecosystem processes under future climate change scenarios. This study further suggests that there is a potential role for macrophytes as bioindicators for the ecological status of Songkhla Lagoon that contributes to the development of a sustainable lake management plan.
\end{abstract}

Keywords: bioindicator, organic content, CCA, lagoon management, anthropogenic change

\section{Introduction}

During the past several centuries since the industrial revolution, human activities have caused strong changes in the structure and function of their environment (Smith et al., 1999). The growth of human population has increased demands on both aquatic and terrestrial ecosystems altering hydrological processes and geochemical cycles of carbon (C), nitrogen (N) and phosphorus (P) (Vitousek et al., 1997a; Smith et al., 1999). Large input of $\mathrm{N}$ and $\mathrm{P}$ into terrestrial systems from agriculture (from the use of fertilizers) and other human activities (e.g. use of detergents, sewage) have increased the nutrient supply in aquatic systems by: 1) accumulating in sediments, and 2) moving from land into surface waters and ground waters (Vitousek et al., 1997b; Smith et al., 1999) which can lead to eutrophication. Steffen et al. (2015) proposed P and N bounds for the earth system at a sustained flow of $11 \mathrm{Tg} \mathrm{P} \mathrm{y}^{-1}$ and $62 \mathrm{Tg} \mathrm{N} \mathrm{y}^{-1}$, respectively; however, the 
current global rates of $\mathrm{P}$ and $\mathrm{N}$ release $\left(22 \mathrm{Tg} \mathrm{P} \mathrm{y}^{-1}\right.$ and $\left.62 \mathrm{Tg} \mathrm{N} \mathrm{y}^{-1}\right)$ already exceed these limits, making eutrophication the major problem in aquatic systems globally (Steffen et al., 2015). Furthermore, the anthropogenic release of greenhouse gases e.g. carbon dioxide $\left(\mathrm{CO}_{2}\right)$ into the atmosphere has led to increased average global temperatures through the trapping of heat by the Greenhouse Effect. As a consequence, surface water temperature has increased and is predicted to increase in the future. Terrestrial, marine and freshwater ecosystems and their resident organisms are expected to be affected by climate change (IPCC, 2007). It is indicated that eutrophication problems will be worsened by the combination of climate change and anthropogenic activities in lakes and estuaries, as this is predicted to occur in many areas in the world (Moss et al., 2010).

Eutrophication is a condition of increased nutrient supply caused by human activities and natural processes as the lakes age and become filled with sediments (Smith et al., 1999). Eutrophication and sediment runoff have usually been the main problems in water quality management of lakes and reservoirs globally, including the Songkhla Lagoon in Southern Thailand (Sompongchaiyakul et al., 2004; Sompongchaiyakul and Sirinawin, 2007; Chesoh and Lim, 2008). Nutrient enrichment induces excessive growth of microalgae, macroalgae and aquatic plants and results in the disruption of ecosystem functions, by depleting the oxygen needed for fish to survive and reducing light penetration to the lake bottom (Smith et al., 1999). Increased temperature can also lead to a higher degree of eutrophication as it promotes growth of algae and aquatic plants and induces algal blooms (Yang et al., 2008). Eutrophication, accumulation of organic matter and increased temperature are also the major threats to benthic vegetation survival in coastal and freshwater environments, leading to a loss of ecosystem function and altered biodiversity (Soana, 2012).

Macrophytes play an important role as ecosystem engineers by acting as habitat structure and refugia for aquatic organisms, maintaining high physical and biological diversity, and ecosystem functions and providing nutrient cycling capacity, and (SandJensen, 1997; Wigand et al., 2000; Cronk and Fennessy, 2001; Qiu et al., 2001). Due to their capacity for nutrient cycling and prevention of phytoplankton blooms, macrophytes can potentially be used as natural tools for sustainable water quality improvement in lakes and reservoirs (Guo-feng et al., 2014; Lone et al., 2014). The growth, photosynthesis and reproduction of submerged macrophytes can be affected by temperature (Barko et al., 1991; Chotikarn et al. 2021a), light (Korschgen et al., 1997; Chotikarn et al. 2021b), and high organic loads in sediments (Barko and Smart, 1983) due to several coupled biological, physical and chemical processes that modify benthic system (Raun et al., 2010). Jiang et al. (2018) showed that Maximum quantum yield $\left(\mathrm{F}_{\mathrm{v}} / \mathrm{F}_{\mathrm{m}}\right)$ of six submerged macrophytes decreased in midday and this was induced by high light. High and low light intensity, which depend on depth, affected growth and biomass of submerged macrophytes by chlorophyll contents changes (Jin et al., 2020). Dissolved organic carbon (DOC) and humic substances (HS) limit macrophyte photosynthesis at greater depths and lead to lower macrophyte abundance and species diversity (Reitsema et al., 2018). Faster organic decomposition and higher oxygen consumption from microbial activity have been reported in organic enriched sediment, which can lead to anoxia in sediments, decreasing plant growth coupled with reduction in chlorophyll content (Atapaththu et al., 2018), greater formation of organic acids and phytotoxic compounds (Pezeshki, 2001; Colmer, 2003), and can induce physiological stresses such as shorter roots and reduced growth (Raun et al., 2010; Møller and Sand- 
Jensen, 2011; Atapaththu et al., 2018). In addition, sediment particle size distribution and physical properties in organic enriched sediments have significant effects on nutrient-holding capacity (Kuriata-Potasznik et al., 2018). Therefore, the different responses of each species of macrophytes to organic enriched sediment can cause a change in species composition in benthic vegetation.

Songkhla Lagoon is a tropical estuarine lagoon system located on the eastern side of the southern Thai Peninsula (Pongpiachan et al., 2019) that not only supports biodiversity and ecosystem functions but also a number of people whose livelihoods depend on that biodiversity via several ecosystem services such as fishery, aquaculture, and tourism (Hue, 2018). However, Songkhla Lagoon is currently experiencing serious water pollution and eutrophication due to human activities, such as release of pesticides and fertilizers from agricultural activities, and nutrient inputs from shrimp farming and livestock waste (Sompongchaiyakul et al., 2004; Pornpinatepong et al., 2010). This could lead to the loss of valuable ecosystem services and functions e.g., carbon sequestration, controlling algal blooms, and nutrient cycling. Several species of submerged macrophytes were observed in Songkhla Lagoon including Ceratophyllum demersum, Cladophora sp., Najas malesiana, Najas marina, Najas graminea, Hydrilla verticillata, and Potamogeton malaianus (Thongkao et al., 2001). Eutrophication is a complex process and is likely to affect each organism in each system differently due to interactions with other factors such as temperature, nutrient loading and light. Hence, it is essential to identify the effects of several environmental factors on these macrophytes in order to successfully manage the lagoon (Howarth et al., 2000).

Due to eutrophication in Songkhla lagoon, ecosystem management is needed to prevent eutrophication. However, there is lack of knowledge about spatial and temporal variations, relation and responses of macrophytes to environmental factors, as well as the roles of submerged macrophytes in nutrient cycling, controlling algal bloom, and carbon storage (Sompongchaiyakul et al., 2004; Sompongchaiyakul and Sirinawin, 2007; Chesoh and Lim, 2008). Thus, this study aims to investigate the spatial and temporal variations in ecophysiology of submerged macrophytes in Songkhla Lagoon, the effects of organic enrichment in sediment on photosynthesis of submerged macrophytes, and the roles of submerged macrophytes in nutrient cycling, controlling algal blooms, and carbon storage. This project could allow for identifying the main driver for growth and photosynthesis of submerged macrophytes and predicting their performance under changing environmental conditions and would allow for the development of sustainable lake management plan and eutrophication model.

\section{Materials and methods}

\section{Experimental design}

To investigate: 1) the spatial and temporal variations in photosynthesis of submerged macrophytes, 2) the effects of organic enrichment in sediment on photosynthesis of submerged macrophytes, 3) the carbon capture potential of submerged macrophytes, and 4) the inhibitory effects of macrophytes on phytoplankton blooms in 3 sites in Songkhla Lagoon, with sites 1, 2 and 3 at near, middle, and far from the lake shore, respectively. Photosynthetic performance (photosynthetic efficiency, leaf pigment; $n=3$ ) and morphology (leaf length, leaf dry weight; $n=10$ ) of submerged macrophytes from high and low organic sediment sites in Songkhla Lagoon were investigated in situ bimonthly for a year covering the rainy and summer seasons. High and low organic 
sediment sites in Songkhla Lagoon were selected for preliminary data on level of organic sediments in Songkla Lagoon (Fig. 1).

Three replicates of submerged macrophytes and sediments $(n=3)$ from each site and time of collection were collected for organic content and carbon $(\mathrm{C})$ and nitrogen $(\mathrm{N})$ content analyses. Sediments $(n=3)$ from each location and time of collection were collected for particle size analysis using a laser particle size analyser (LPSA) (LS230, Beckman Coulter, USA). Water ( $2 \mathrm{~L})(n=3)$ from each location and time of collection was collected for phytoplankton biomass and nutrient (phosphate and nitrate) analyses. Dissolved oxygen, light intensity, air and water temperature, salinity, $\mathrm{pH}$, turbidity, and rainfall data were collected. Rainfall, maximum and minimum sea surface temperature (SST), and wind speed in Kukud, Songkhla Lagoon area were collected from State of the Ocean (2018).

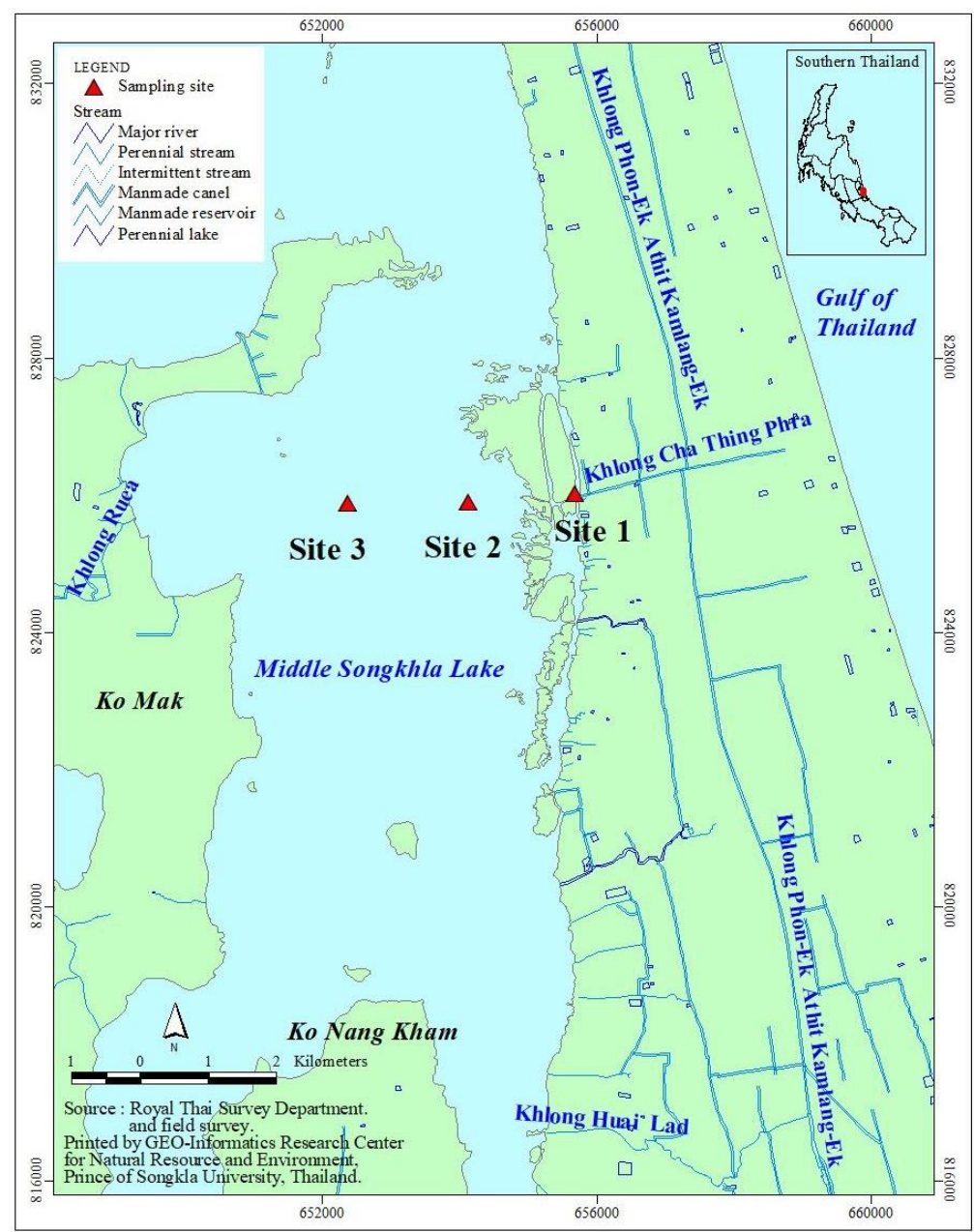

Figure 1. Map showing Site $1\left(7^{\circ} 28^{\prime} 18.2{ }^{\prime \prime} N 100^{\circ} 24^{\prime} 37.8^{\prime \prime} E\right)$, Site $2\left(7^{\circ} 28^{\prime} 16.7^{\prime \prime} \mathrm{N}\right.$ $100^{\circ} 23^{\prime} 46.1$ ' E) and Site 3 (7'28'13.0”N 100 22'51.7”'E) in Kukud, Songkhla Lagoon

\section{Percentage cover of submerged macrophytes}

Percentage cover of submerged macrophytes from each time of collection was randomly estimated in $50 \times 50 \mathrm{~cm}^{2}$ quadrats $(n=3)$. Macrophytes along water body in quadrat were estimated in percentage by visual census, modified from Mellors (1991). 


\section{Photosynthetic efficiency}

The photosynthetic performances of each species of submerged macrophyte found at each site and time of sampling were investigated by determining Rapid Light Curves (RLCs) $(n=3)$ at the same time each day, using a 6-millimeter diameter fiberoptic probe connected to a pulse-amplitude modulated (PAM) fluorometer (MINI-PAM, Walz, Germany). RLCs with 9 increasing actinic light intensities $(0,149,215,383,450$, $806,1074,1658,2576 \mu \mathrm{mol}$ photons $\mathrm{m}^{-2} \mathrm{~s}^{-1}$ ) were applied, with $0.8 \mathrm{~s}$ saturating pulses ( $>4500 \mu \mathrm{mol}$ photons $\mathrm{m}^{-2} \mathrm{~s}^{-1}$ ) between each actinic light intensity every $10 \mathrm{~s}$. Effective quantum yield of PSII ( $\Delta \mathrm{F} / \mathrm{F}_{\mathrm{M}}{ }^{\prime}$; Schreiber, 2004), maximum relative electron transport rate $\left(\mathrm{rETR}_{\max }\right)$, minimum saturating irradiance $\left(\mathrm{I}_{\mathrm{k}}\right)$ and initial slope $(\alpha)$ of RLCs were calculated using the curve fitting protocols in Ralph and Gademann (2005).

\section{Leaf pigments}

Photosynthetic pigment concentration (chlorophyll (Chl) $a$ and $b$ ) of submerged macrophytes were determined using the standard spectrophotometric method of Ritchie (2006). Chlorophyll $a$ and $b\left(\mu \mathrm{g} \mathrm{g}^{-1}\right.$ fresh weight (fw)) were extracted by homogenizing samples in $4 \mathrm{ml}$ of $90 \%$ acetone at $4{ }^{\circ} \mathrm{C}$ for $24 \mathrm{~h}$. Samples $(n=3)$ were centrifuged at $1500 \mathrm{~g}$ for $10 \mathrm{~min}$ and the supernatant placed into a quartz cuvette in a spectrophotometer (SP8001, Metertech Inc., Taiwan), and the absorbance was measured at 647,664 and $750 \mathrm{~nm}$.

\section{Organic content in macrophytes and sediments}

Macrophyte samples $(n=3)$ were oven dried at $105{ }^{\circ} \mathrm{C}$ and ground to a particle size of less than $1 \mathrm{~mm}$. A $1.0 \mathrm{~g}$ ground sample was ashed in a muffle furnace (FHX, DAIHAN, China) at $550{ }^{\circ} \mathrm{C}$ for $8 \mathrm{~h}$ (Armecin and Gabon, 2008). Sediment samples were oven dried at $105{ }^{\circ} \mathrm{C}$ and a $1.0 \mathrm{~g}$ dried sample was ashed at $550{ }^{\circ} \mathrm{C}$ for $4 \mathrm{~h}$. Organic matter in macrophytes was determined using the data obtained from the ashed samples on mineral matter (MM) (Eq. 1), as the organic matter (OM) (Eq. 2) and organic carbon (OC) (Eq.3) contents were computed using the following equations:

$$
\begin{gathered}
\% \mathrm{MM}=(\mathrm{AW} / \mathrm{DW}) \times 100 \\
\% \mathrm{OM}=100 \times(\mathrm{DW}-\mathrm{AW}) / \mathrm{DW} \\
\% \mathrm{OC}=\% \mathrm{OM} / 1.724
\end{gathered}
$$

where AW and DW are ash weight and dry weight of the sample, respectively.

\section{Sediment composition}

Sediment samples $(n=3)$ were collected using a $60 \mathrm{~mm}$ corer for grain size distribution and organic content analysis. Texture of each sample (grain size distribution) was investigated using a laser particle size analyzer (LS 230, Beckman Coulter, USA). Sediment $<2 \mathrm{~mm}$ in diameter was classified into eight size classes (clay, silt, fine sand, and coarse sand at <3.9, 3.9-62.5, 62.5-500, and 500-2000 $\mu \mathrm{m}$, respectively). 


\section{Carbon and nitrogen contents in macrophytes and sediment}

Carbon and nitrogen contents in sediments were analyzed with a standard method using a carbon nitrogen analyser (CN628, Leco, USA) at Office of Scientific Instruments and Testing (OSIT), Prince of Songkla University, Thailand.

\section{Carbon capture potential}

Macrophyte samples were dried at $60{ }^{\circ} \mathrm{C}$ for $96 \mathrm{~h}$ in an oven and weighted. All the samples were ground in a laboratory fine grinder and then passed through a 40-mesh screen before further analysis. Carbon content in each macrophyte species was analyzed by carbon nitrogen analyser (CN628, Leco, USA). Ash content was analyzed by heating at $600{ }^{\circ} \mathrm{C}$ in a muffle furnace (FHX, DAIHAN, China). Higher heating values ( $\left.\mathrm{HHV}_{\text {ult }}\right)$ were estimated from the carbon composition using the ultimate analysis formula (Sheng and Azevedo, 2005).

$$
\text { HHVult }(\mathrm{MJ} / \mathrm{kg})=0.3259(\text { Carbon content }(\%))+3.4597
$$

In addition, higher heating values $\left(\mathrm{HHV}_{\text {prox }}\right)$ were also estimated from the carbon composition using the proximate analysis formula (Sheng and Azevedo, 2005).

$$
\text { HHVprox }(\mathrm{MJ} / \mathrm{kg})=19.914-0.2324(\text { Ash }(\%))
$$

Carbon and ash contents $(n=3)$ for each macrophyte species were analyzed from the equal mixture of oven dried samples collected each time at each plot in each site.

\section{Phytoplankton biomass}

Phytoplankton biomass was determined as chlorophyll $a$ concentration in water column. Water samples $(150 \mathrm{ml})(n=3)$ were filtered through $25-\mathrm{mm} \mathrm{GF} / \mathrm{F}$ filters under dim light and pigments on filters were extracted with $100 \%$ acetone. The mixture was sonicated for $45 \mathrm{~s}$ on ice and the extracts were stored at $0{ }^{\circ} \mathrm{C}$ in the dark for $30 \mathrm{~min}$. The extracts were then centrifuged at $2000 \mathrm{~g}$ for $5 \mathrm{~min}$. Chlorophyll $a$ in the supernatant was determined spectrophotometrically using equations of Jeffrey and Humphrey (1975) (Doblin et al., 1999).

\section{Statistical analysis}

Two-way ANOVA tests were used to test for significant differences among sites over time in chlorophyll fluorescence parameters $\left(\Delta \mathrm{F} / \mathrm{F}_{\mathrm{M}}, \mathrm{rETR}_{\max }, \mathrm{I}_{\mathrm{k}}, \alpha\right)$, leaf pigments, morphological properties, species composition, organic content, $\mathrm{C}$ and $\mathrm{N}$ contents, particle size distribution, nutrient, chlorophyll $a$ in water column, and other physical parameters. All tests were performed with a significance level of $95 \%$, and Tukey's honestly significant difference post hoc tests were used to identify the statistically distinct groups. If data did not meet the assumptions of normality (Kolmogorov-Smirnov test) and equal variance (Levene's test), the data were transformed using square root or $\log _{10}$. If transformed data did not meet the assumptions, non-parametric tests were used. Canonical Correspondence Analysis (CCA) was used to assess the relationship between biological and environmental variables among sites and times using MVSP (Kovach Computing Services). 


\section{Results}

\section{Environmental parameters}

Environmental data from State of the Ocean (2018)

Lowest rainfall was found in March 2018, while highest rainfall was observed in February 2018. Average SST in Kukud, Songkhla Lagoon from May 2017 to May 2018 ranged from 28 to $31^{\circ} \mathrm{C}$. Lowest average SST was found in February 2018 $\left(28.318 \pm 0.106{ }^{\circ} \mathrm{C} / 24 \mathrm{~h}\right)$, while highest average temperature was observed in May 2018 $\left(31.113 \pm 0.072{ }^{\circ} \mathrm{C} / 24 \mathrm{~h}\right)($ Table 1). Rainfall and SST data indicate that March to July represented dry season, while October to February was the rainy season in this area. Wind speed ranged from 1.2 to $2.3 \mathrm{~km} \mathrm{hr}^{-1}$.

\section{Water quality}

Water depth and transparency showed spatial variation $(\mathrm{P}<0.001)($ Fig. 2a, b) in which water level was the shallowest in site 1 and the deepest in site 3 ( $\mathrm{P}<0.001)$; and the water level at all sites increased with the highest rainfall in February 2018 while transparency was highest at site 3 and lowest at site $1(\mathrm{P}<0.001)$. Water temperature and SST showed similar trends (Table 1) at all sites (Fig. 2c) being highest at site 1 and lower at sites 2 and $3(\mathrm{P}<0.001)$.

Table 1. Mean \pm SE of rainfall, maximum and minimum sea surface temperature (SST), and wind speed in Kukud, Songkhla Lagoon area from May 2017 to May 2018 (State of the Ocean, 2018) (mean \pm SE)

\begin{tabular}{c|c|c|c|c}
\hline Times & $\begin{array}{c}\text { Rainfall } \\
(\mathbf{m m} / \mathbf{2 4} \mathbf{h})\end{array}$ & $\begin{array}{c}\text { Max SST } \\
\left({ }^{\circ} \mathbf{C} / \mathbf{2 4} \mathbf{h}\right)\end{array}$ & $\begin{array}{c}\text { Min SST } \\
\left({ }^{\circ} \mathbf{C} / \mathbf{2 4} \mathbf{h}\right)\end{array}$ & $\begin{array}{c}\text { Wind speed } \\
(\mathbf{k m} / \mathbf{h})\end{array}$ \\
\hline May: 2017 & $9.30 \pm 1.98$ & $30.85 \pm 0.09$ & $30.70 \pm 0.09$ & $2.06 \pm 0.22$ \\
July: 2017 & $3.11 \pm 0.57$ & $30.69 \pm 0.03$ & $30.54 \pm 0.03$ & $1.61 \pm 0.26$ \\
Oct: 2017 & $13.67 \pm 2.07$ & $30.37 \pm 0.07$ & $30.22 \pm 0.07$ & $1.97 \pm 0.35$ \\
Feb: 2018 & $33.30 \pm 9.99$ & $28.47 \pm 0.08$ & $28.32 \pm 0.11$ & $2.32 \pm 0.29$ \\
Mar: 2018 & $1.40 \pm 0.00$ & $29.93 \pm 0.08$ & $29.78 \pm 0.08$ & $1.29 \pm 0.24$ \\
May: 2018 & $12.29 \pm 2.54$ & $31.11 \pm 0.07$ & $30.96 \pm 0.07$ & $1.19 \pm 0.23$ \\
\hline
\end{tabular}

Temporal variation was seen in water temperature with the lowest water temperature found in March 2018 and the highest water temperature observed in May 2018 $(\mathrm{P}<0.001)$. Total Dissolved Solid (TDS) showed temporal variation $(\mathrm{P}<0.001)$ with the lowest value in February 2018 and the highest in May 2018 (Fig. 2d). Water salinity showed temporal variation $(\mathrm{P}<0.001)$ with the lowest salinity in March 2018 and the highest in May 2018 (Fig. 2e). Water $\mathrm{pH}$ showed both spatial and temporal variations $(\mathrm{P}<0.001)$ at sites 2 and 3 being higher from May to October 2017 and lower from February to May 2018 (Fig. 2f). 

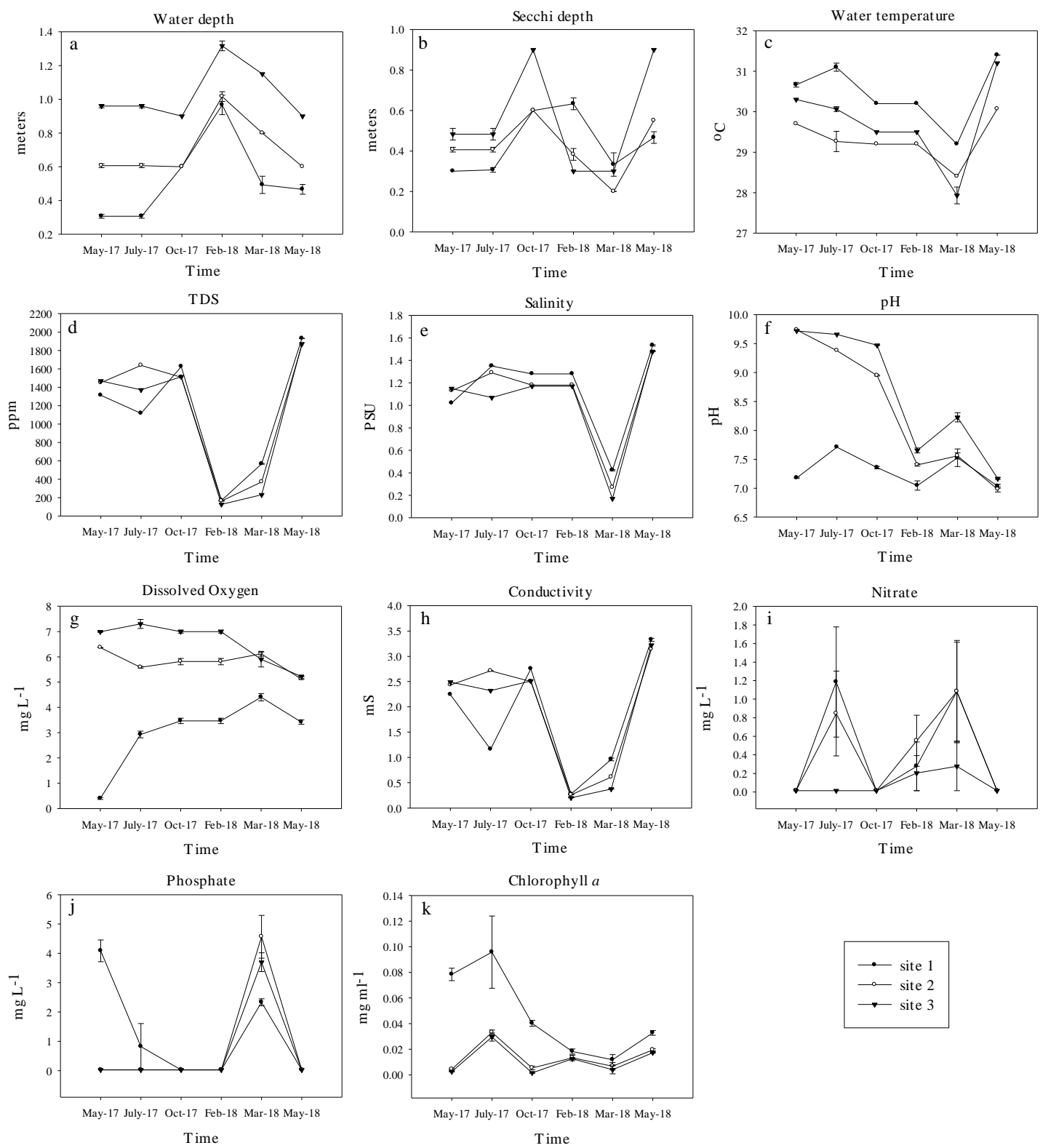

Figure 2. Water depth (a), secchi depth (b), water temperature (c), TDS (d), salinity (e), pH (f), dissolved oxygen (g), conductivity (h), nitrate (i) and phosphate concentration (j) and chlorophyll a concentration (k) in Kukud, Songkhla Lagoon area from May 2017 to May 2018 (Data presented as mean $\pm S E$ )

There were temporal variations in dissolved oxygen concentration (DO) $(\mathrm{P}<0.001)$ at site 1, while sites 2 and 3 had higher DO from May 2017 to March 2018 and slightly decreased level in May 2018. DO at site 3 was significantly higher than at sites 1 and 2 $(\mathrm{P}<0.001)$ (Fig. 2g). Water conductivity showed temporal variations $(\mathrm{P}<0.001)$ at all sites and the highest conductivity was observed in May 2018, while the lowest conductivity was found in February 2018 (P<0.001) (Fig. 2h). There was no significant difference in nitrate concentration among the sites (1,2 and 3) at any time of collection $(\mathrm{P}>0.05)$. The phosphate concentration was significantly higher at sites 1 and $2(\mathrm{P}=0.003$ and 0.028) (Fig. 2i, $j$ ). Chlorophyll $a$ concentration in water was 
significantly higher at site $1(\mathrm{P}<0.001)$ and in May and July $2017(\mathrm{P}<0.001)$, which indicates elevated concentration of phytoplanktons and possible eutrophication during the dry season (Fig. $2 k$ ).

\section{Sediment characteristics}

Organic matter $(\mathrm{OM})$ and organic carbon $(\mathrm{OC})$ in sediment from site 1 were significantly higher than at sites 2 and 3 at all times of collection $(\mathrm{P}<0.001)$. Site 2 also had significantly higher $\mathrm{OM}$ and $\mathrm{OC}$ than site $3(\mathrm{P}=0.014)$. There was no significant difference in $\mathrm{OM}$ or $\mathrm{OC}$ among the times of collection $(\mathrm{P}>0.05)$ except that in May 2017 these were significantly higher than at other times $(\mathrm{P}<0.001)$ (Fig. 3).
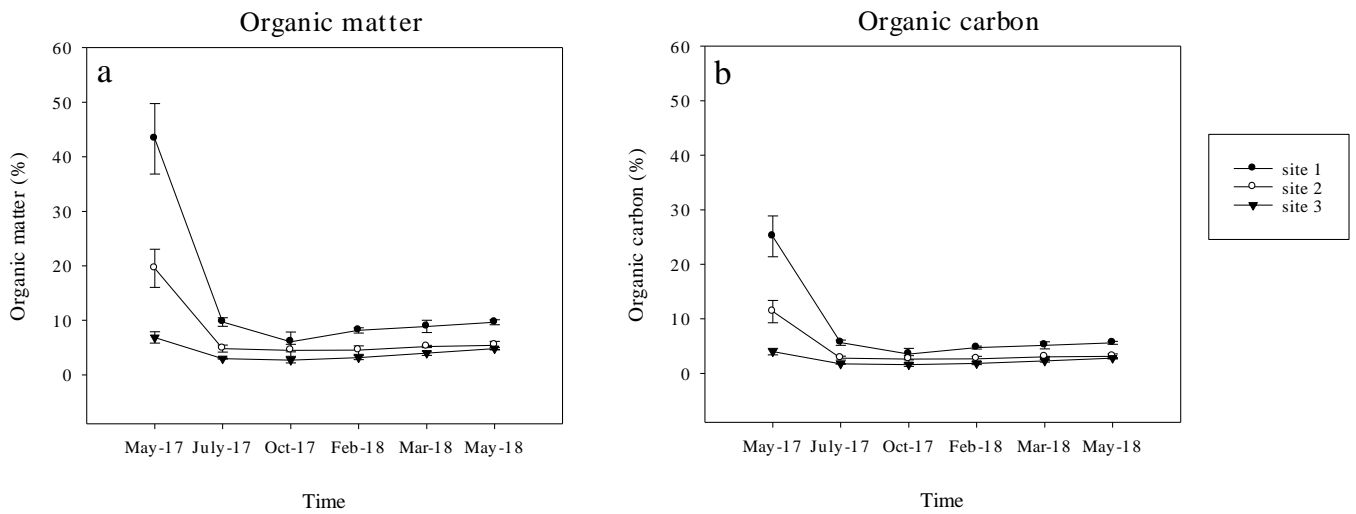

Figure 3. Organic matter (a) and organic carbon (b) in sediment from sites 1 - 3 (Near, Mid, Far) in Kukud, Songkhla Lagoon area from May 2017 to May 2018 (data presented as mean $\pm S E)$

Carbon $(\mathrm{C})$ and Nitrogen $(\mathrm{N})$ contents in sediment from site 1 were significantly higher than at sites 2 and 3 for all times of collection $(\mathrm{P}<0.001)$ except for October 2017 and February 2018 ( $\mathrm{P}>0.05)$. There was no significant difference in $\mathrm{C}$ or in $\mathrm{N}$ among the times of collection in sites 2 and 3 (P > 0.05) (Fig. 4a, b). C:N ratios at site 1 were significantly higher than at sites 2 and 3 for all times of collection $(\mathrm{P}<0.001)$ (Fig. 4c). At site 1, C and N contents were significantly higher in May, July 2017 and March and May $2018(\mathrm{P}<0.001)$, while C:N ratio was significantly higher in October 2017 and February 2018 (P < 0.001) (Fig. 4c) (Table A2).

Sediment in Kukud, Songkhla Lagoon was classified as silt. Large proportions of silt, clay, fine sand and coarse sand were observed. There were no significant differences in percentages of clay, silt, fine sand and coarse sand among sites and times of collection $(\mathrm{P}>0.05)$ (Fig. 5).

\section{Similarity of environmental parameters among sites and times of collection}

The analysis of similarity of environmental parameters among sites and times of collection was done by using Cluster Analysis (CA). All environmental parameter data including wind speed, rainfall, sea surface temperature, water temperature, depth, secchi depth, salinity, dissolved oxygen concentration, $\mathrm{pH}$, nitrate, phosphate, Chl a concentration, conductivity, TDS, organic matter and organic carbon, $\mathrm{C}$ and $\mathrm{N}$ contents, $\mathrm{C}: \mathrm{N}$ ratios in sediments, and sediment particle size were used in the analyses. The 
results show two distinct clusters with $80.10 \%$ similarity. First cluster is T1Near, which had different environmental parameters from the other sites and times. Second cluster (Cluster 2) had $87.06 \%$ similarity and was separated into 2 clusters: Cluster 3 with 88.50\% similarity (T1Mid, T1Far, T3Mid, T3Far, T2Mid, T2Far, T3Near, T6Near, T6Mid, T6Far, T4Near, T4Mid and T4Far) and Cluster 4 with $88.91 \%$ similarity (T2Near, T5Near, T5Mid and T5Far).
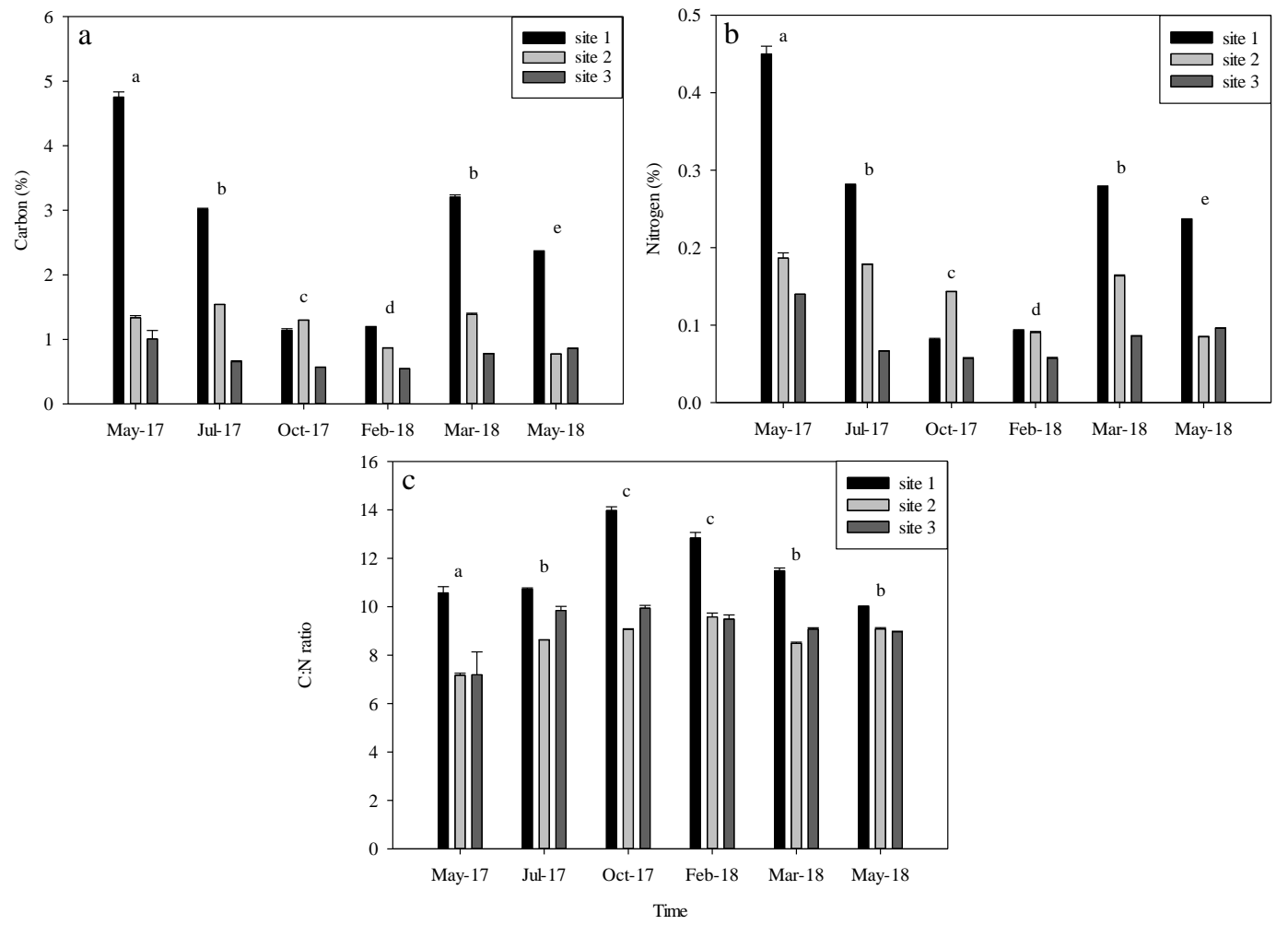

Figure 4. Carbon $(C ;$ a) and nitrogen $(N ; b)$ contents and $C: N$ ratios in sediments from sites $1-$ 3 (Near, Mid, Far) in Kukud, Songkhla Lagoon area from May 2017 to May 2018 (data represent mean $\pm S E$ )

When the similarity of environmental parameters among times was analyzed regardless of study site, we found that May 2017 was distinct from the other times of collection (Cluster 1 with 87.06\% similarity). Cluster 2 (March 2018) had 89.67\% similarity and cluster 3 (July and October 2017 and February and May 2018) had 90.48\% similarity. Environmental parameters in July and October 2017 and May 2018 had $95 \%$ similarity. This indicates temporal variations in the environmental parameters among observation times.

When the similarity of environmental parameters among sites was analyzed regardless of time, the results showed two distinct clusters with $92.11 \%$ similarity where site 1 (Near) was different from the other sites. Site 2 (Mid) and 3 (Far) had $97.01 \%$ similarity.

\section{Percentage cover of submerged macrophytes}

Temporal and spatial variations in percentage cover and composition of free floating and submerged macrophytes and macroalgae were observed in this study (Fig. 6). Eight 
species were observed namely Cladophora sp., Ceratophyllum demersum, Salvinia cucullata, Potamogeton malaianus, Najas marina, Najas graminea, Chara zeylanica and Elodea Canadensis during May 2017 to May 2018. Highest macrophyte cover was found in site 3 , while site 1 had a significantly lower percentage cover of submerged macrophytes than sites 2 and 3 ( $\mathrm{P}<0.001$ ). From May to October 2017, submerged macrophytes cover was highest in sites 2 and 3, while no macrophytes were observed at site 1 in February to May 2018 and at site 2 in February to March 2018 (Table Al) which were in the rainy season.
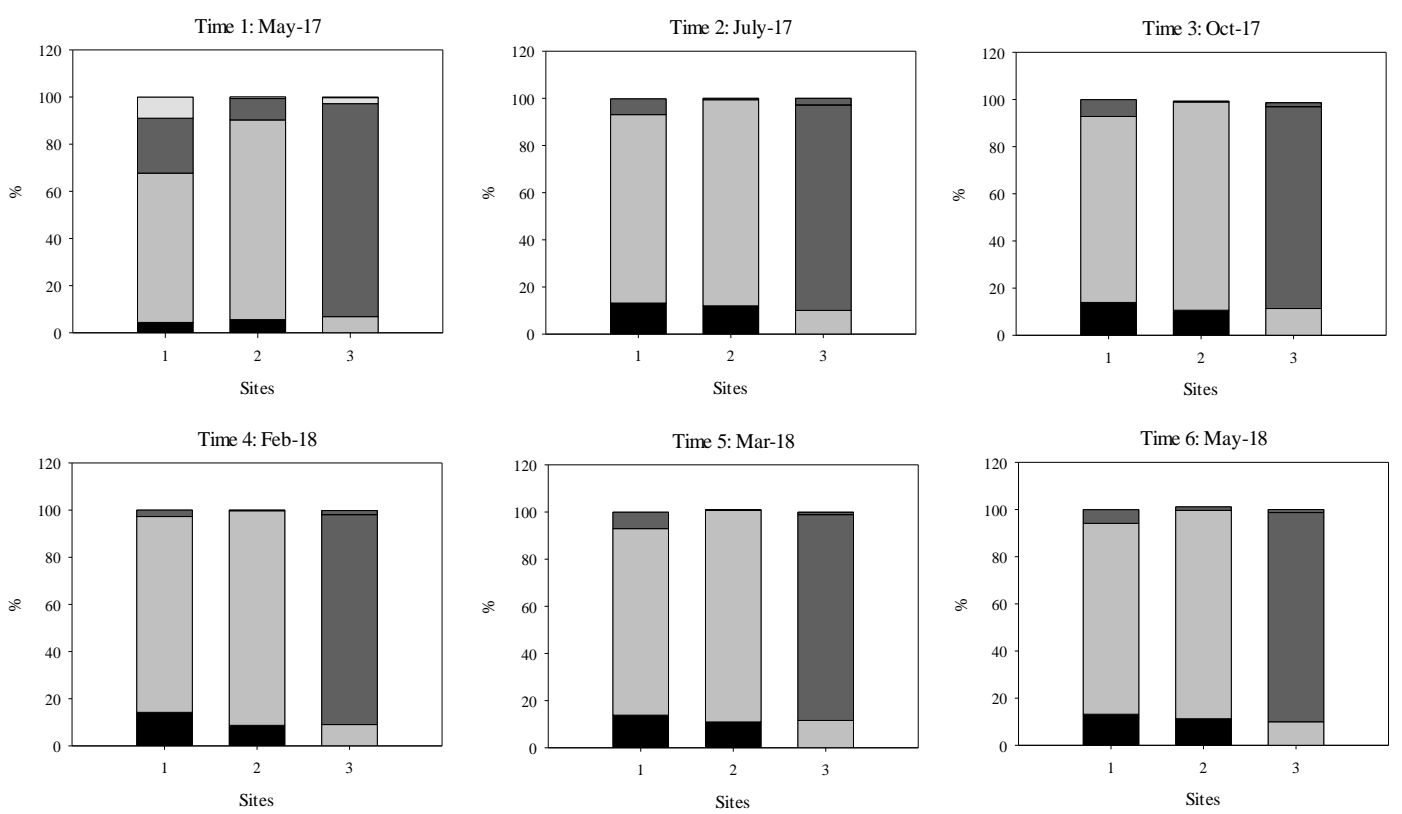

Clay $\rightleftharpoons$ Silt $\rightleftharpoons$ Fine sand $\Longleftarrow$ Coarse sand

Figure 5. Particle size proportions (clay, silt, fine sand, and coarse sand) of sediments from sites 1 - 3 (Near, Mid, Far) in Kukud, Songkhla Lagoon area from May 2017 to May 2018 (data represent mean $\pm S E)$

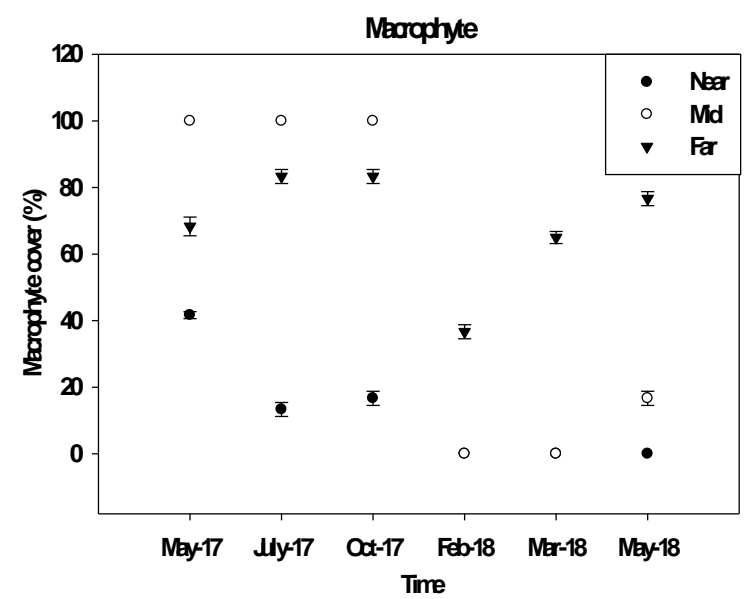

Figure 6. Percentage cover of submerged macrophytes from three locations (sites $1-3$ (Near, Mid, Far)) in Kukud, Songkhla Lagoon from May 2017 to May 2018 (data represent mean $\pm S E$ ) 
Cladophora sp. cover was significantly higher in May to October 2017 at site 2 ( $\mathrm{P}<0.001)$ (Table A2), while there were no Cladophora sp. at sites 1 and 3 at any time of collection except for May 2017 and October 2018, respectively. C. demersum was only observed in site 1 in May to October 2017 and site 2 in May to July 2017. S. cucullata was only observed in site 1 in May and July 2017. P. malaianus was only observed in sites 2 and 3 and high percentage cover was found at site 3 in October 2017, and March and May 2018. N. marina was observed at site 1 in May to October 2017 and May 2018 and at site 3 in May to July 2017. N. graminea was only found at site 2 from May to July 2017 and at site 3 from May to October 2017. High percentage cover of $C$. zeylanica was found at site 2 from May to October 2017. E. canadensis showed highest percentage cover at site 3 from July 2017 to May 2018.

\section{Photosynthesis of submerged macrophytes}

Effective quantum yield of PSII (Y(II)), which indicates photosynthetic efficiency of C. Demersum, was significantly higher at site 1 than at site $2(\mathrm{P}<0.001)$ (Fig. 7; Table A3). There were no significant differences in Y(II) among sites and times of sampling observed in $P$. malaianus, $N$. marina, $N$. graminea, $C$. zeylanica and $E$. canadensis $(\mathrm{P}>0.05)$. Saturating irradiance $\left(\mathrm{I}_{\mathrm{k}}\right)$ showed no significant differences among sites and times of sampling observed in $C$. demersum, $P$. malaianus, $N$. marina, $N$. graminea, C. zeylanica and E. canadensis $(\mathrm{P}>0.05)$ (Fig. 7). There were significant differences in maximum relative electron transport rate $\left(\mathrm{rETR}_{\max }\right)$ among sites and times of sampling observed in C. demersum, P. malaianus, and $N$. graminea, $(\mathrm{P}>0.05)$ (Fig. 7). rETR $\mathrm{max}_{\max }$ of N. marina, C. zeylanica in October 2017 was significantly higher than that at the other times of sampling $(\mathrm{P}=0.006$ and $\mathrm{P}=0.047$, respectively). $\mathrm{rETR}_{\max }$ of E. canadensis was significantly lower in July $2017(\mathrm{P}=0.018)$. There were no significant differences in Alpha among sites and times of sampling observed in $C$. demersum, $P$. malaianus, $N$. marina, N. graminea, C. zeylanica and E. Canadensis $(\mathrm{P}>0.05)$ (Fig. 7).

\section{Morphology (leaf length, leaf dry weight)}

There were no significant differences in leaf length among sites and times of sampling observed in $C$. demersum, $P$. malaianus, $N$. marina, $N$. graminea, $C$. zeylanica and E. canadensis (P > 0.05) (Fig. 8).

There were no significant differences in leaf dry weight among sites and times of sampling observed in P. malaianus, C. zeylanica and E. canadensis $(\mathrm{P}>0.05)$ (Fig. 8) (Table A3). Leaf dry weight of $C$. demersum was significantly higher at site 2 than at site $1(\mathrm{P}=0.024)$. In $N$. marina, leaf dry weight was significantly higher at site 3 than at site $2(\mathrm{P}=0.001)$, while this was reversed in $N$. graminea $(\mathrm{P}<0.001)$.

\section{Organic contents}

Organic matter (OM) and organic carbon (OC) contents of $C$. demersum were significantly lower at site 1 in May 2017 compared to other sites and times of sampling $(\mathrm{P}<0.05)$ (Fig. 9). There were significant differences in $\mathrm{OM}$ and $\mathrm{OC}$ among sites and times of sampling observed in P. malaianus and C. demersum $(\mathrm{P}>0.05)$ (Table A3). Significantly higher $\mathrm{OM}$ and $\mathrm{OC}$ at site 2 compared to site 3 were observed in $N$. marina, N. graminea and C. zeylanica $(\mathrm{P}<0.001, \mathrm{P}<0.001$ and $\mathrm{P}=0.001$, respectively). 


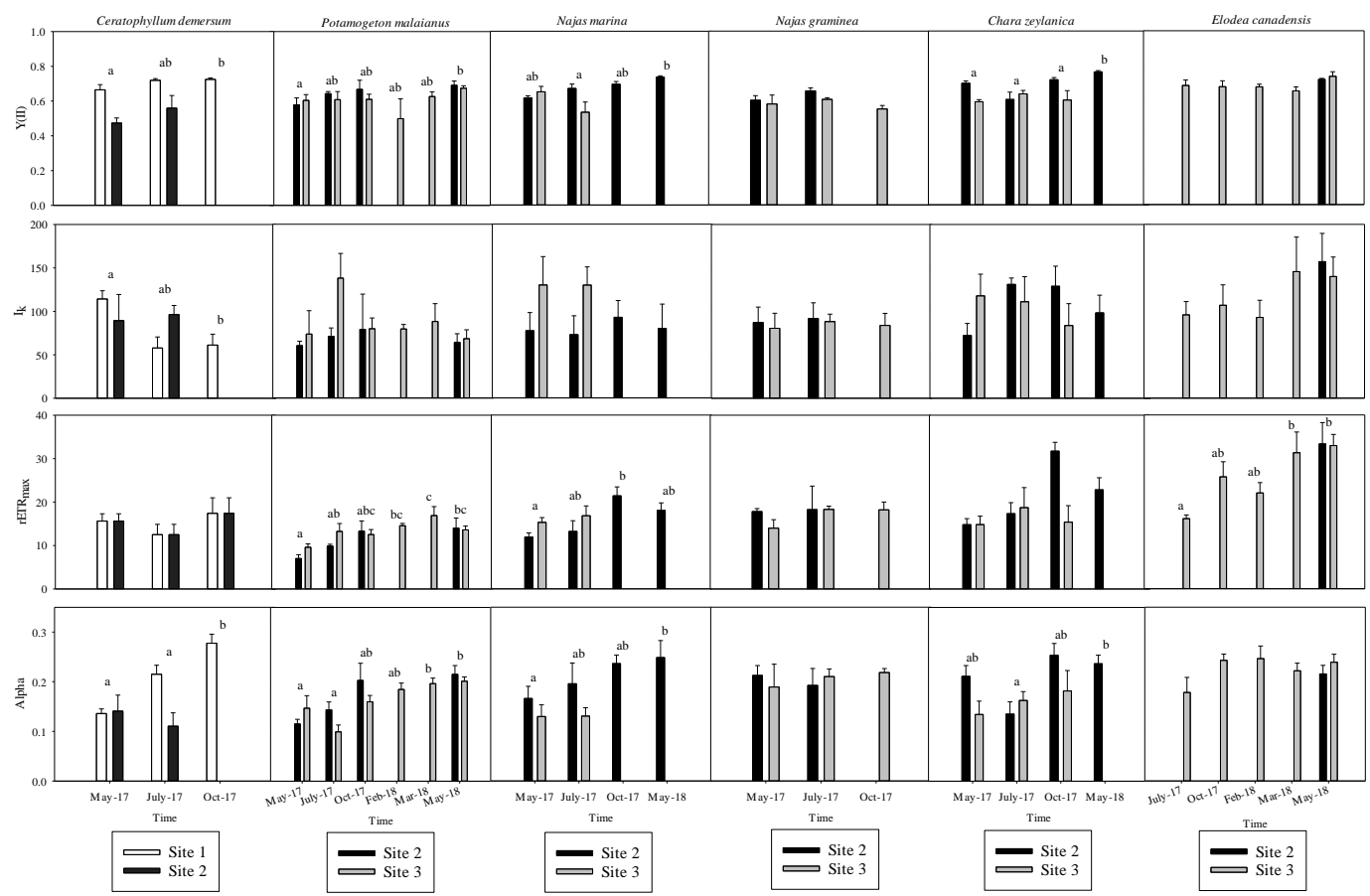

Figure 7. Photosynthetic efficiency $(Y(I I))$, saturating irradiance $\left(I_{k}\right)$, maximum relative electron transport rate (rETR max $_{\text {) }}$ and Alpha of Ceratophyllum demersum, Potamogeton malaianus, Najas marina, Najas graminea, Chara zeylanica and Elodea canadensis from three locations (sites 1-3 (Near, Mid and Far)) in Kukud, Songkhla Lagoon from May 2017 to May 2018 (data represent mean \pm SE)
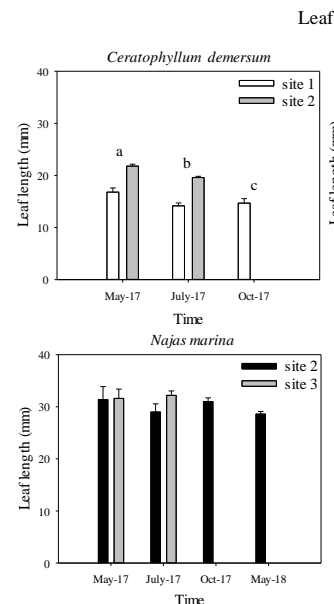

Time

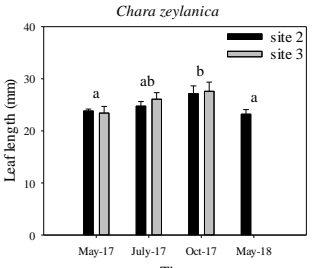

Leaf length
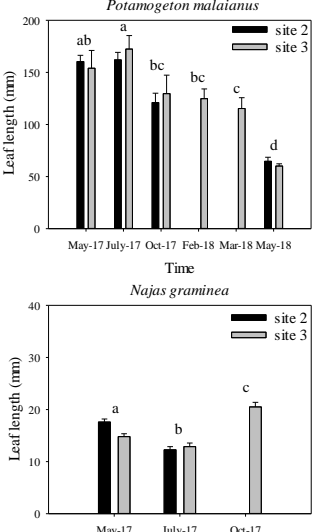

July-17
Time

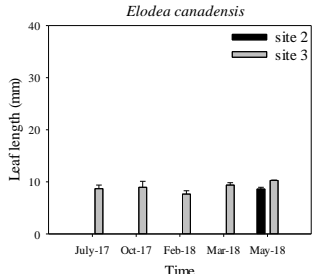

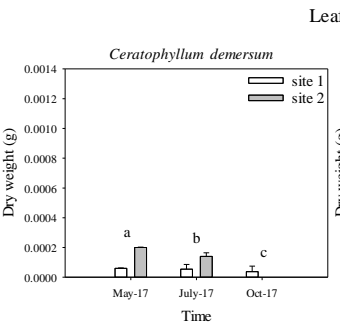
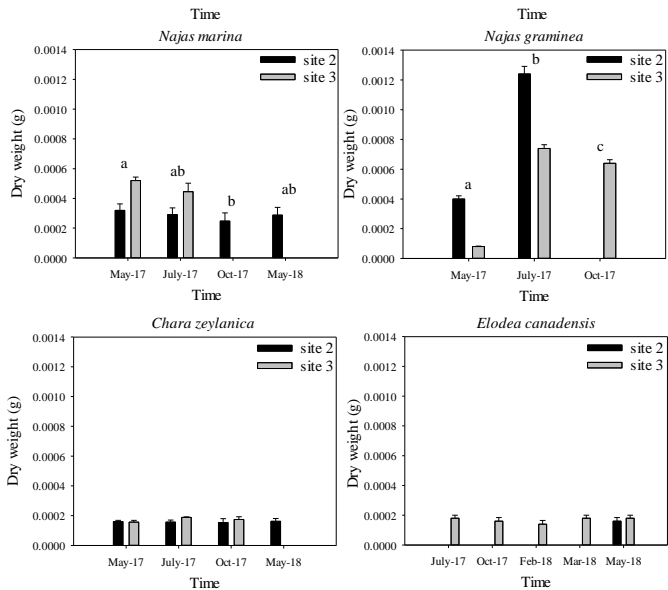

Time

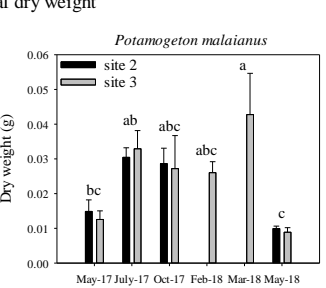

Time

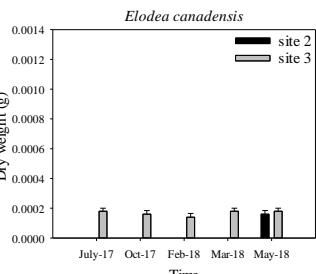

Figure 8. Leaf length and Leaf dry weight of Ceratophyllum demersum, Potamogeton malaianus, Najas marina, Najas graminea, Chara zeylanica and Elodea canadensis from three locations (sites 1-3 (Near, Mid and Far)) in Kukud, Songkhla Lagoon from May 2017 to May 2018 (data represent mean \pm SE) 

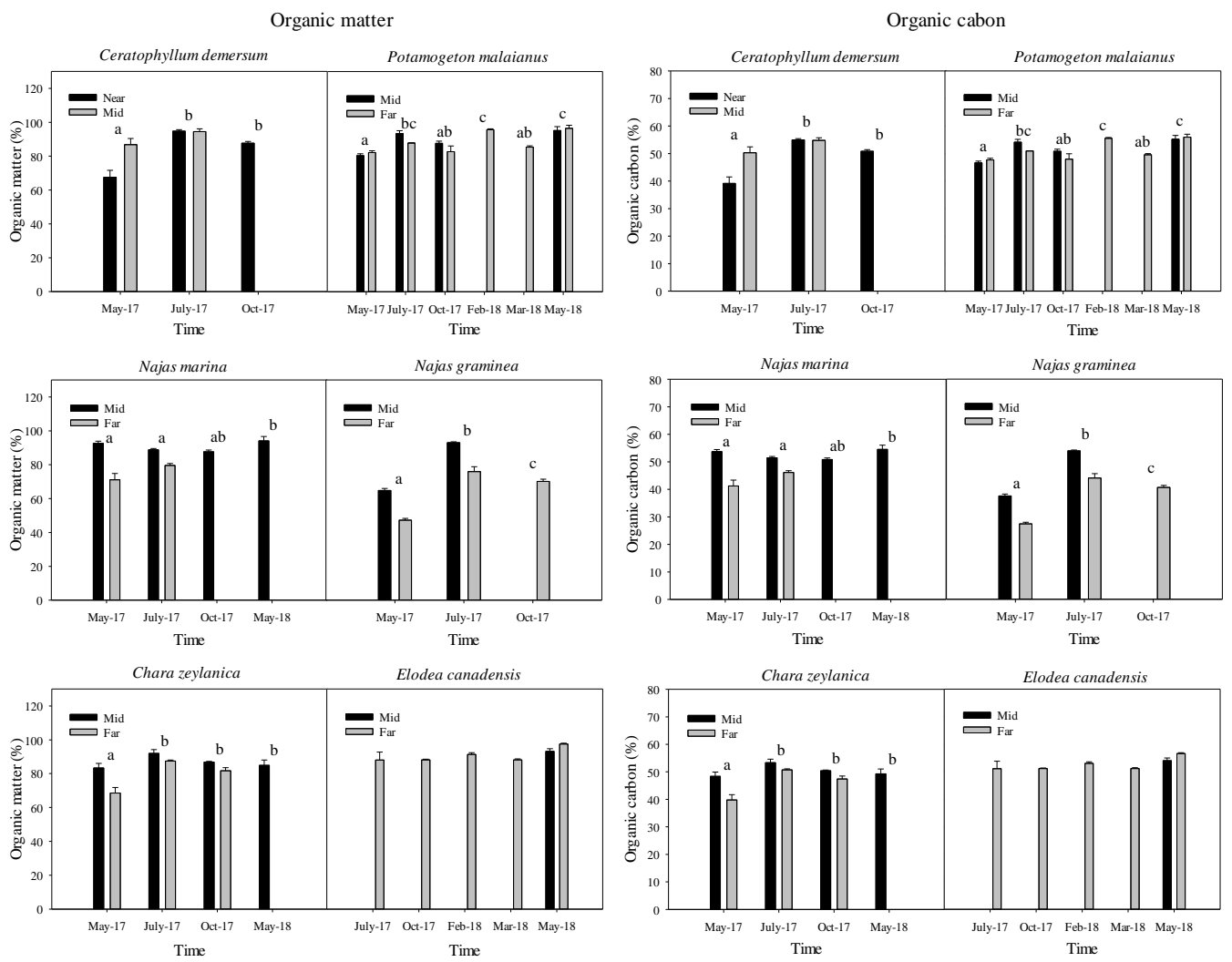

Figure 9. Organic matter and organic carbon contents of Ceratophyllum demersum,

Potamogeton malaianus, Najas marina, Najas graminea, Chara zeylanica and Elodea canadensis from three locations (sites 1-3 (Near, Mid and Far)) in Kukud, Songkhla Lagoon from May 2017 to May 2018 (data represent mean \pm SE)

\section{CCA}

CCA showed relationships among environmental parameters and biological parameters of macrophytes indicating that depth, wind, water quality, dissolved oxygen, nitrate and phosphate concentration in water, carbon and nitrogen contents, and silt concentration in sediment had significant impacts on biology of submerged macrophytes with $90.74 \%$ and Eigenvalue 0.03 (Fig. Al). Higher organic matter content in submerged macrophytes was related to higher depth, while EQY, $\mathrm{rETR}_{\max }, \mathrm{I}_{\mathrm{k}}$, Alpha, $\mathrm{HHV}_{\text {ult }}$ and $\mathrm{HHV}_{\text {prox }}$ were high at higher wind. Percentage cover of submerged macrophytes was found at higher silt concentration in sediment and high $\mathrm{pH}$, while water depth, dissolved oxygen in water, and organic matter, organic carbon, $\mathrm{C}$ and $\mathrm{N}$ contents, and silt and fine sand contents in sediment had significant impact on percentage cover of submerged macrophytes with $83.94 \%$ and Eigenvalue 0.823 (Fig. A2). High percentage cover of macrophytes was observed with high dissolved oxygen. $C$. demersum and $S$. cucullata were found in area with high $\mathrm{Chl} a$ in water. High N. marina and C. zeylanica were found at high water $\mathrm{pH}$, while E. canadensis and $P$. malaianus were high at increased depth and secchi depth.

CCA indicated that $\mathrm{Chl} a$ concentration in submerged macrophytes was influenced by water depth, TDS, nitrate concentration in water and organic carbon, organic contents, C, N and fine sand contents in sediment with $89.49 \%$ and Eigenvalue 0.491 (Fig. A3). Chl $a$ concentration in submerged macrophytes was related to water depth. 
High Chl $a$ content in $C$. demersum was found in area with high nitrate concentration. High Chl $a$ content in S. cucullata, N. marina, C. zeylanica and P. malaianus were found in area with high organic matter and organic content in sediment but it was lowest at increased depth. High Chl $a$ content E. canadensis was found at increased depth.

Then, CCA showed that effective quantum yield (EQY) and alpha of macrophytes were associated with chlorophyll $a$ in water, water depth, dissolved oxygen, nitrate and phosphate in water and organic matter, organic carbon, $\mathrm{C}$ and $\mathrm{N}$ contents and silt and fine sand contents in sediment with $92.53 \%$ and $87.88 \%$ and Eigenvalues of 1.000 and 0.729, respectively (Figs. A4 and A5). EQY and alpha of Najas marina, Najas graminea, Chara zeylanica were high in area with high dissolved oxygen, $\mathrm{pH}$ and conductivity and silt sediment, while EQY and alpha of E. canadensis and P. malaianus were high in area with higher depth and secchi depth, while rETR $_{\max }$ and $\mathrm{I}_{\mathrm{k}}$ of macrophytes were influenced by chlorophyll $a$ in water, dissolved oxygen, water depth, nitrate and phosphate in water and organic matter, organic carbon, $\mathrm{C}$ and $\mathrm{N}$ contents, and silt contents in sediment with $83.33 \%$ and $89.50 \%$ and Eigenvalues of 0.484 and 0.644, respectively (Figs. A6 and A7). $\mathrm{rETR}_{\max }$ and $\mathrm{I}_{\mathrm{k}}$ of $C$. demersum were high in area with high phosphate, nitrate and Chl $a$ in water, while $\mathrm{rETR}_{\max }$ and $\mathrm{I}_{\mathrm{k}}$ of Najas marina, Najas graminea, Chara zeylanica were high in area with high dissolved oxygen, $\mathrm{pH}$ and silt sediment. $\mathrm{rETR}_{\max }$ and $\mathrm{I}_{\mathrm{k}}$ of E. canadensis and P. malaianus were high in area with higher depth and secchi depth.

CCA indicated that organic matter of macrophytes was influenced by depth, water salinity, organic matter, organic carbon, $\mathrm{C}$ and $\mathrm{N}$ contents, and fine sand and coarse sand contents in sediment with $88.15 \%$ and Eigenvalue 0.474 (Fig. A8). Carbon in sediment has largest effect on organic matter of macrophytes. Organic matter of $S$. cucullata, $N$. marina, and $C$. canadensis was high in area with high salinity, while it was low in area with high rainfall and water depth. Organic matter of E. canadensis and $P$. malaianus was high in area with higher depth and clay sediment, while organic carbon of macrophytes was influenced by depth, $\mathrm{pH}$, secchi depth, organic matter, organic carbon, $\mathrm{C}$ and $\mathrm{N}$ contents, and clay contents in sediment with $90.08 \%$ and Eigenvalue 0.647 (Fig. A9). Carbon in sediment has the largest effect on organic carbon of macrophytes. Organic carbon of $N$. graminea, $N$. marina, and $C$. zeylanica was high in area with elevated $\mathrm{pH}$. Organic carbon of E. canadensis and P. malaianus was high in area with increased depth, secchi depth and clay sediment.

\section{Carbon capture potential}

$\mathrm{HHV}_{\text {ult }}$ and $\mathrm{HHV}_{\text {prox }}$ of submerged macrophytes collected from Kukud, Songkhla were between $12.05-22.07 \mathrm{MJ} \mathrm{kg}^{-1}$ and $7.23-19.80 \mathrm{MJ} \mathrm{kg}^{-1}$, respectively (Fig. 10). $\mathrm{HHV}_{\text {ult }}$ in $C$. demersum, $N$. gramine and Chara zeylanica varied among sites and times of sampling $(\mathrm{P}<0.05)$ (Table A3). There were no significant differences in $\mathrm{HHV}_{\mathrm{ult}}$ and $\mathrm{HHV}_{\text {prox }}$ of $P$. malaianus and E. Canadensis among sites and times of sampling $(\mathrm{P}>0.05)$. $\mathrm{HHV}_{\text {ult }}$ and $\mathrm{HHV}_{\text {prox }}$ in $N$. marina, N. graminea and C. zeylanica were significantly higher at sites 2 and $3(\mathrm{P}<0.05)$.

CCA showed that chlorophyll $a$ in water column, depth, secchi depth, dissolved oxygen, nitrate concentration in water, organic matter, organic carbon, and silt content in sediment had significant impacts on $\mathrm{HHV}_{\text {ult }}$ and $\mathrm{HHV}_{\text {prox }}$ of submerged macrophytes while silt content had the most significant effect (Figs. AlO and A11). Higher HHV ult and $\mathrm{HHV}_{\text {prox }}$ in $C$. demersum would be found in an area with high phosphate, nitrate and chlorophyll $a$ concentration in water and high organic matter and organic carbon in 
sediment. On the other hand, $\mathrm{HHV}_{\text {ult }}$ and $\mathrm{HHV}_{\text {prox }}$ in $N$. marina, N. graminea and $C$. zeylanica would be high in an area with high dissolved oxygen and $\mathrm{pH}$ in water and silt sediment. E. canadensis and P. malaianas would have high $\mathrm{HHV}_{\mathrm{ult}}$ and $\mathrm{HHV}_{\text {prox }}$ under higher depth and clay sediment.
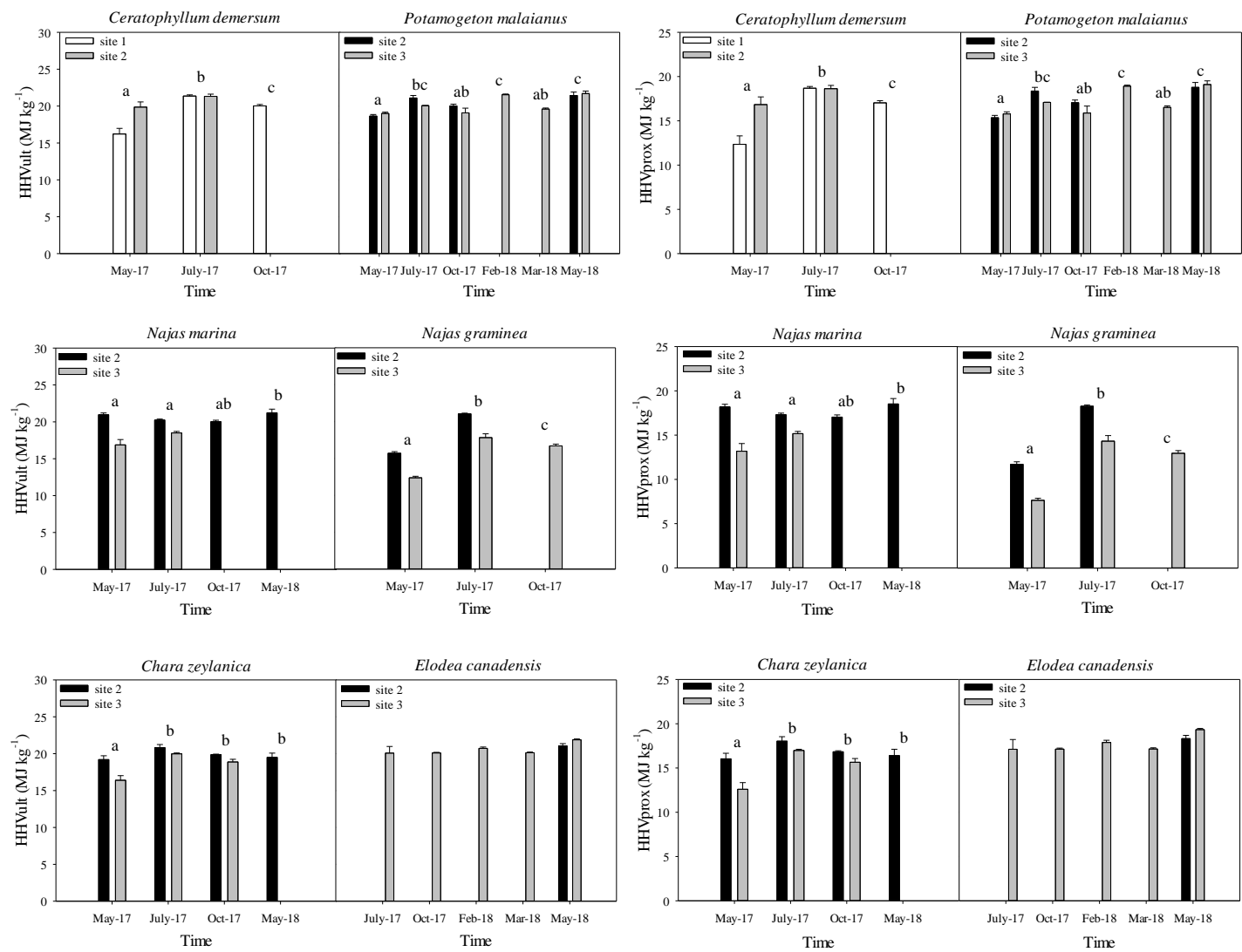

Figure 10. $H H V_{u l t}$ and $H H V_{\text {prox }}$ of submerged macrophytes in Kukud, Songkhla Lagoon area from May 2017 to May 2018

\section{Relationship between submerged macrophytes and phytoplankton bloom}

This study used chlorophyll a concentration in water as an indicator of phytoplankton bloom. Linear regression showed a negative relationship between submerged macrophytes and phytoplankton bloom $\left(\mathrm{P}<0.001, \mathrm{R}^{2}=0.057\right)$ (Fig. 11). Multiple regression among submerged macrophytes, nitrate and phosphate concentration and chlorophyll a in water showed significant relationship among these parameters $\left(\mathrm{P}<0.001, \mathrm{R}^{2}=0.381\right)$.

\section{Discussion}

\section{Spatial and temporal variations in photosynthesis of macrophytes}

Six from twenty-one species of submerged macrophytes found in Songkhla Lagoon and one species of macroalgae were observed in the middle lake (Kukud) in this study. These include a floating plant (Salvinia cucullata), submerged plants (Ceratophyllum demersum, Najas marina, Potamogeton malaianuis, Elodea canadensis, Chara 
zeylanica and Najas graminea), and algae (Cladophora sp.). There are spatial and temporal variations in photosynthetic capacity, growth and species composition of submerged macrophytes.

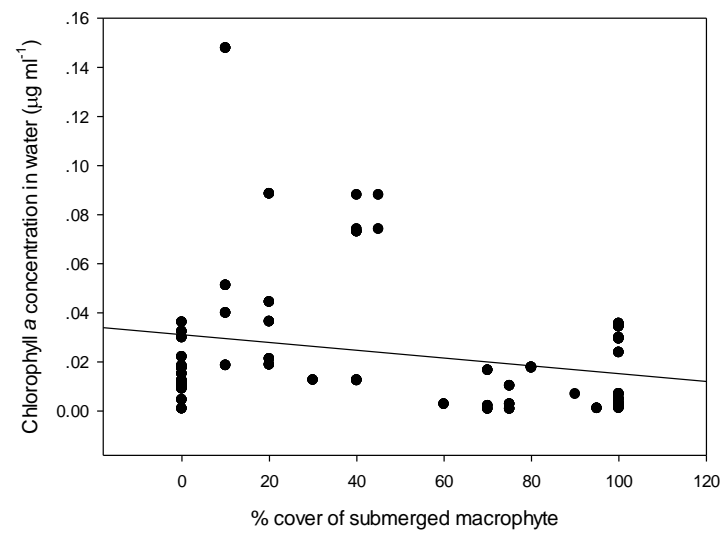

Figure 11. Relationship between \% cover of submerged macrophyte and chlorophyll a concentration in Kukud, Songkhla Lagoon area from May 2017 to May 2018

Site 1 had significantly lower percentage cover of submerged macrophytes than sites 2 and 3 and presented only $C$. demersum and $S$. cucullata, which might be due to high nutrients and Chl $a$ in water. It is suggested that trophic status is the major ecological determinant of the floristical composition (Sahu et al., 2020). C. demersum was found in site 1, which has high nutrients and high turbidity. This study confirms that $C$. demersum is an indicator of eutrophication in a lake. In lowland rivers with different habitat conditions, Bytyqi et al. (2020) found that the presence of macrophyte species varies by nutrient level, and macrophyte based indices represent the water quality. Further, macrophytes can serve as tools for biomonitoring heavy metals in river water (Yasar et al., 2019).

Macrophyte cover correlated with rainfall being low in high rainfall (February) and increasing with low rainfall (October). Cladophora sp. cover was significantly higher in May to October 2017 at site 2, while there were no Cladophora sp. at sites 1 or 3 at any time of collection except for May 2017 and October 2018, respectively. N. graminea was only found at site 2 from May to July 2017 and at site 3 from May to October 2017. High percentage cover of $C$. zeylanica was found at site 2 from May to October 2017. This might be due to fluctuations of several parameters, such as nutrients in water and sediment, turbidity, light availability, and water flow (Hilt et al., 2018; Schneider et al., 2018).

Songkhla lagoon water bodies are exposed to frequent water level fluctuations due to rainfall, freshwater run-off, and tides, which leads to a high instability of habitats and might affect macrophyte species composition and abundance (Schneider et al., 2018). For example, particle resuspension or turbidity could limit light availability for photosynthesis and growth (Reitsema et al., 2018). Water flow can directly reduce submerged macrophyte biomass due to the strong mechanical strain and the damage caused to plant tissues via breaking and uprooting (Zhang et al., 2014; Schneider et al., 2018). Changes of water depth could be catastrophic for submerged macrophytes (devoid of cuticle and supporting tissues) when exposed to air conditions or to very large floods (Sousa et al., 2010; Schneider et al., 2018). Our study showed P. malaianus 
and E. canadensis as abundant at site 3, which had more depth, higher light and lower turbidity. P. malaianus might have a high breaking strength and high phenotypic plasticity (Brewer and Parker 1990; Idestam-Almquist and Kautsky, 1995; Hilt et al., 2018) while E. canadensis has been found to be in deep water and possess a lower tensile strength (Brewer and Parker, 1990).

It has been suggested that light and water flow are important factors that influence submerged macrophytes (Zhang et al., 2012; Schneider et al., 2018). However, the macrophytes found in this study were rooted submerged macrophytes. Therefore, nutrient status in sediment could play a significant role in determining abundance of these submerged macrophytes. CCA showed that water depth, dissolved oxygen in water, and organic matter, organic carbon, $\mathrm{C}$ and $\mathrm{N}$ contents, and silt and fine sand contents in sediment had significant impact on percentage cover of submerged macrophytes. Therefore, a combination of several factors could play a significant role to these submerged macrophytes.

\section{Effect of sediment enrichment on macrophytes photosynthesis}

CCA showed that photosynthetic capacity (Effective quantum yield of PSII, alpha, saturating irradiance, and maximum relative electron transport rate) is influenced by several factors such as chlorophyll $a$ in water, water depth, dissolved oxygen, nitrate and phosphate in water and organic matter, organic carbon, $\mathrm{C}$ and $\mathrm{N}$ contents, and silt and fine sand contents in sediment. Lower photosynthetic efficiency (effective quantum yield) was observed in area with more silt and clay sediment. This is consistent with findings in Ruan et al. (2010) which suggest that highly enriched sediment reduced leaf chlorophyll, leaf biomass and root length due to plant stress. Organic enrichment can enhance organic decomposition, oxygen consumption and acid formation, which lead to anoxia in sediment and roots and greater formation of organic acids, $\mathrm{S}^{-2}, \mathrm{Fe}^{2+}$ and $\mathrm{Mn}^{2+}$, which results in physiological stress. This stress can reduce root length, growth of plant and rood anchorage (Schutten et al., 2005; Ruan et al., 2010). The responses of macrophytes to organic enriched sediments are also species specific and the effects could be stronger on rooted macrophytes. For example, Lobelia dortmanna could have critically poor anchorage on highly organic sediments as the anoxic sediments impair root development (Sand-Jensen and Møller, 2014). As a result of the varied responses by species, this can cause changes to the species composition and reduce the variety of species found in benthic vegetation.

\section{Ability of macrophytes to capture carbon and factors that affect carbon capture potential}

One of the options to cope with the climate change issue is carbon capture and sequestration by natural ecosystems (Wang et al., 2011; Maqbool and Khan, 2013). An aquatic system (known as blue carbon habitat) can capture atmospheric $\mathrm{CO}_{2}$ via photosynthesis by photosynthetic organisms such as macrophytes, mangrove, and seagrass, and convert it into a permanent form of fixed carbon stored in live tissues and sediments (McLeod et al., 2011; Trevathan-Tackett et al., 2015). It is found that blue carbon system is more efficient at long-term carbon sequestration than are terrestrial systems (Trevathan-Tackett et al., 2015). The inland lake waters, which cover only $2.1 \%$ of the global landscape, contribute $260 \mathrm{~g} \mathrm{C} \mathrm{m}^{-2} \mathrm{y}^{-1}$ of net primary productivity, suggesting that the inland lakes can be sinks for carbon. With high growth rate, high 
productivity (545 $\mathrm{mg} \mathrm{C} \mathrm{m}^{-2} \mathrm{~d}^{-1}$ ) and fragmentation of submerged macrophytes, they could make a significant contribution as carbon donors to blue carbon sediments. In addition, macrophyte biomass has potential for bioenergy production (Wang et al., 2011).

Organic carbon content of macrophytes was influenced by water depth, $\mathrm{pH}$, secchi depth and sediment characteristics and varied by site and time of sampling. The mechanism of carbon sequestration through photosynthesis depends on several factors that influence growth of plants, like temperature, light, and nutrients. Therefore, summer season with higher temperature and more light could lead to higher carbon sequestration potential. However, too high levels of light and temperature could reduce photosynthesis and growth due to photosynthetic stresses, and lead to reduced carbon sequestration (Lolu et al., 2018). Moreover, higher nutrient status of lake leads to higher carbon sequestration (Kvet et al., 2008).

Highest organic carbon contents and $\mathrm{HHV}_{\mathrm{ult}}$ and $\mathrm{HHV}_{\text {prox }}$ were found in $P$. malaianus, E. canadensis and N. marina and they are in the same range as submerged macrophytes reported in Wang et al. (2011). It is suggested that carbon contents were positively correlated with $\mathrm{HHV}_{\text {ult }}$ and $\mathrm{HHV}_{\text {prox }}$, and negatively correlated with ash content.

\section{Macrophytes as phytoplankton bloom inhibitors}

Eutrophication is indicated by excessive growth of algae, cyanobacteria and macrophytes (Penning et al., 2008) due to relaxing one or more limitations of growth factors needed for photosynthesis, such as light, low $\mathrm{CO}_{2}$, temperature, and nutrients such as phosphorus and nitrogen (Chislock et al., 2013). These nutrients are essential for algal growth (Scholten et al., 2005). Therefore, eutrophication results in an increase in algal and cyanobacteria productivity (bloom), which will subsequently reduce light availability for other photosynthetic species such as macrophytes and will result in poor water quality such that the water is anoxic and toxic (Scholten et al., 2005). The management and restoration of a lake suffering from eutrophication is challenging. It is suggested that nutrients $(\mathrm{N}, \mathrm{P})$ can be removed by biological processes, such as photosynthesis, respiration, fermentation, nitrification ( $\mathrm{N}$ only), de-nitrification ( $\mathrm{N}$ only), microbial activity; and by physical processes such as solute transport which was influenced by longitudinal dispersion. (Riis et al., 2020). It has been shown that submerged macrophytes can play an important role in controlling phytoplankton in enclosed shallow water bodies (Guo-feng et al., 2014). Macrophytes have a high capacity for absorption of nutrients ( $\mathrm{N}$ and $\mathrm{P}$ ) directly from the water, they store nutrients for long periods, and the accumulation of macrophyte biomass leads to $\mathrm{N}$ limitation for the phytoplankton (Guo-feng et al., 2014).

This study used chlorophyll $a$ concentration in water as an indicator of phytoplankton bloom. Linear regression showed a negative relationship between submerged macrophytes and phytoplankton bloom and multiple regression among submerged macrophytes, nitrate and phosphate concentration and chlorophyll $a$ in water showed significant relationship among these parameters. The results suggest that macrophytes could potentially be used for controlling phytoplankton blooms. However, the types and amounts of macrophytes used for nutrient removal should be considered as they differ in nutrient uptake, growth rate and physical structure (Lee et al., 2009). It has been shown that macrophytes also produce allelopathic substances, which can destroy the cell structure of algae and affect photosynthesis, respiration, and enzymatic 
activity of algal cells (Mohamed, 2017). This can lead to a competitive advantage over other macrophytes and phytoplankton (Mohamed, 2017). It has been found that allelochemicals of macrophyte Myriophyllum spicatum decreased the photosynthesis activity of Microcystis aeruginosa (Zhu et al., 2010) and macrophyte assemblages had greater allelopathic effect on cyanobacteria and diatoms than monocultured macrophytes (Rojo et al., 2013). Moreover, we found high percentage cover of macrophytes with high dissolved oxygen, which indicates that the macrophytes are a source of oxygen in the lake and play an important role in the functioning of aquatic ecosystem by changing water quality parameters, such as turbidity, total organic carbon, total nitrogen, and chemical oxygen demand (Souza et al., 2015; Lv et al., 2018). These changes can affect epiphytic algal community structure due to high transparency, low nutrient concentration and more habitats and spatial niches for epiphytic algae (Lv et al., 2018).

This study suggests that macrophytes can be used to improve water quality of the lake or lagoon by nutrient removal which will help manage an eutrophic lake. The suitable submerged macrophyte biomass for lake management could be determined. Excessive amount of submerged macrophytes can be problematic to human activities and affect ecosystem services of the lake. It is suggested that when submerged macrophyte biomass is more than $6000 \mathrm{~g} \mathrm{~m}^{-2}$, dissolved oxygen concentration becomes too low for the survival of fish and invertebrates and a suitable submerged macrophyte biomass range is $3000-6000 \mathrm{~g} \mathrm{~m}^{-2}$ (Ishikawa et al., 2019). The actions to manage excessive macrophytes include reduction and elimination methods: mechanical (e.g., hand tools, mechanical devices), environmental (e.g., light, nutrients), chemical (e.g., herbicides, deoxygenation) and biological methods (e.g., grass carp) (Cabrera Walsh et al., 2017; Hussner et al., 2017; Ishikawa et al., 2019). Moreover, excessive macrophytes can be used as sources of feedstock for incineration or bioenergy production while unattended macrophyte biomass could become detritus organics and transform at the sediment layer into methane, which is a greenhouse gas, and nutrient uptake by the macrophytes can be partially returned to the water body (Wang et al., 2011).

This study confirms that water quality and environmental conditions of the lake related to both human activities and natural events are important for abundance, diversity, and distribution of submerged macrophytes in Songkhla Lagoon. Nutrients (nitrogen and phosphorus), light, and water flow are important factors. It is suggested that the relationship between environmental parameters and composition of macrophytes can be a helpful tool for predicting ecosystem processes under future climate change scenarios (Schneider et al., 2018). Reduction of nutrients is a priority for lake management in order to compensate for the increased eutrophication due to global warming (Stefanidis et al., 2019).

\section{Conclusions}

This study showed temporal and spatial variations in photosynthesis, growth, carbon sequestration potential and bioenergy potential of submerged macrophytes. It is suggested that trophic status might be a major ecological determinant of the floristical composition. As climate change is currently an issue, future research on the impacts of climate change on macrophytes and lagoonal ecosystems could be pursued. Interactive effects of elevated temperature, light, nutrient enrichment, and acidification on macrophyte species, community structure and lagoonal ecosystem functions could be 
determined and predicted. This project suggests that the relationship between environmental parameters and composition of macrophytes can be a helpful tool providing bioindicators of the ecological status; for predicting ecosystem processes of Songkhla Lagoon under future climate change scenarios; and can contribute to the development of a sustainable lake management plan.

Acknowledgements. We thank Pimchanok Buapet, Raymond Ritchie, Mikael Kim and Oramas Suttinun for their valuable support. We would also like to thank the Division of Biological Science, Faculty of Science, Prince of Songkla University (PSU), Faculty of Environmental Management, PSU, Marine and Coastal Resources Institute, PSU, and Coastal Oceanography and Climate Change Research Center, PSU for research facilities. This work was supported by the Thailand Research Fund and co-funded by The Commission of Higher Education [Grant number MRG6080129]; Prince of Songkla University [Grant number ENV59026N and Grant number COR59024N]. Authors would like to thank Assoc. Prof. Seppo Karrila and Research and Development Office, PSU for English language check.

\section{REFERENCES}

[1] Armecin, R. B., and Gabon, F. M. (2008): Biomass, organic carbon and mineral matter contents of abaca (Musa textilis Nee) at different stages of growth. - Industrial Crops and Products 28: 340-345.

[2] Atapaththu, K. S. S., Parveen, M., Asaeda, T., Rashid, M. H. (2018): Growth and oxidative stress response of aquatic macrophyte Myriophyllum spicatum to sediment anoxia. - Fundamental and Applied Limnology 191(4): 289-298.

[3] Barko, J. W., Smart, R. M. (1983): Effects of organic matter additions to sediment on the growth of aquatic plants. - Journal of Ecology 71: 161-175.

[4] Barko, J. W., Smart, R. M., McFarland, D. G. (1991): Interactive effects of environmental conditions on the growth of submersed aquatic macrophytes. - Journal of Freshwater Ecology 6: 199-207.

[5] Brewer, C. A., Parker, M. (1990): Adaptations of macrophytes to life in moving water: upslope limits and mechanical properties of stems. - Hydrobiologia 194: 133-142.

[6] Bytyqi, P., Czikkely, M., Shala-Abazi, A., Fetoshi, O., Ismaili, M., Hyseni-Spahiu, M., Ymeri, P., Kabashi-Kastrati, E., Millaku, F. (2020): Macrophytes as biological indicators of organic pollution in the Lepenci River Basin in Kosovo. - Journal of Freshwater Ecology 35(1): 105-121.

[7] Cabrera Walsh, G., Hernández, M. C., McKay, F., Oleiro, M., Guala, M., Sosa, A. (2017): Lessons from three cases of biological control of native freshwater macrophytes isolated from their natural enemies. - Aquatic Ecosystem Health \& Management 20(4): 353-360.

[8] Chesoh, S., Lim, A. (2008): Forecasting fish catches in the Songkhla Lake basin. ScienceAsia 34: 335-340.

[9] Chislock, M. F., Doster, E., Zitomer, R. A., Wilson, A. E. (2013): Eutrophication: causes, consequences, and controls in aquatic ecosystems. - Nature Education Knowledge 4: 1-10.

[10] Chotikarn, P., Kaewchana, P., Prathep, A., Roekngandee, P., Sinutok, S. (2021): Effect of in situ experimental shading on the photosyhtnesis of Canadian waterweed (Elodea canadensis) from Songkhla Lagoon, Thailand. - Applied Ecology and Environmental Research 19(3): 2593-2604.

[11] Chotikarn, P., Kaewchana, P., Roekngandee, P., Pramneechote, P., Prathep, A., Sinutok, S. (2021): Combined effects of warming and shading on growth and photosynthetic performance of submerged macrophytes from Songkhla Lagoon, Thailand. - Applied Ecology and Environmental Research 19(3): 2575-2592. 
[12] Colmer, T. D. (2003): Long-distance transport of gases in plants: a perspective on internal aeration and radial oxygen loss from roots. - Plant Cell and Environment 26: 17-36.

[13] Cronk, J. K., Fennessy, M. S. (2001): Wetland Plants: Biology and Ecology. - CRC Press, Boca Raton, pp. 61-83.

[14] Doblin, M. A., Blackburn, S. I., Hallegraeff, G. M. (1999): Growth and biomass stimulation of the toxic dinoflagellate Gymnodinium catenatum (Graham) by dissolved organic substances. - Journal of Experimental Marine Biology and Ecology 236: 33-47.

[15] Guo-Feng, L., Zhang, L., Cheng-Xin, F., Shi-Qun, H., Jun, H., Paerl, H. W. (2014): The response of macrophytes to nutrients and implications for the control of phytoplankton blooms in East Taihu Lake, China. - Journal of Pollution, Effects and Control 2: 113.

[16] Hilt, S., Nuñez, M. M. A., Bakker, E. S., Blindow, I., Davidson, T. A., Gillefalk, M., Hansson, L. A., Janse, J. H., Janssen, A. B. G., Jeppesen, E., Kabus, T., Kelly, A., Köhler, J., Lauridsen, T. L., Mooij, W. M., Noordhuis, R., Phillips, G., Rücker, J., Schuster, H. H., Søndergaard, M., Teurlincx, S., Weyer, K., Donk, E., Waterstraat, A., Willby, N., Sayer, C. D. (2018): Response of submerged macrophyte communities to external and internal restoration measures in north temperate shallow lakes. - Frontiers in Plant Science 9: 1-24.

[17] Howarth, R. W., Cloern, J. E., Anderson, D. M., Hopkinson, C. (2000): Nutrient pollution of coastal rivers, bays and seas. - Issues in Ecology 7: 1-13.

[18] Hue, H. T. T. (2018): Shrimp and fish catch landing trends in Songkhla Lagoon, Thailand during 2003-2016. - Applied Ecology and Environmental Research 16(3): 3061-3078.

[19] Hussner, A., Stiers, I., Verhofstad, M. J. J. M., Bakker, E. S., Grutters, B. M. C., Haury, J., van Valkenburg, J. L. C. H., Brundu, G., Newman, J., Clayton, J. S., Anderson, L. W. J., Hofstra, D. (2017): Management and control methods of invasive alien freshwater aquatic plants: a review. - Aquatic Botany 136: 112-137.

[20] Idestam-Almquist, J., Kautsky, L. (1995): Plastic responses in morphology of Potamogeton pectinatus L. to sediment and above-sediment conditions at two sites in the northern Baltic proper. - Aquatic Botany 52: 205-216.

[21] IPCC, Climate Change (2007) The Physical Science Basis. - In: Solomon, S. et al. (eds.) Contribution of Working Group I to the Fourth Assessment Report of the Intergovernmental Panel on Climate Change. Cambridge Univ. Press, Cambridge, UK, and New York.

[22] Ishikawa, K., Haga, H., Inoue, E., Ban, S. (2019): Determining suitable submerged macrophyte biomass in terms of dissolved oxygen concentration and biodiversity in the South Basin of Lake Biwa, Japan. - Limnology 20: 69-82.

[23] Jeffrey, S. W., Humphrey, G. F. (1975): New spectrophotometric equations for determining chlorophylls $a, b, c_{1}$ and $c_{2}$ in higher plants, algae and natural phytoplankton. - Biochemie und Physiologie der Pflanzen 167: 191-194.

[24] Jiang, H. S., Zhang, Y., Yin, L., Li, W., Jin, Q., Fu, W., Zhang, T., Huang, W. (2018): Diurnal changes in photosynthesis by six submerged macrophytes measured using fluorescence. - Aquatic Botany 149: 33-39.

[25] Jin, S., Ibrahim, M., Muhammad, S., Khan, S., Li, G. (2020): Light intensity effects on the growth and biomass production of submerged macrophytes in different water strata. - Arabian Journal of Geosciences 13(18): 948.

[26] Korschgen, C. E., Green, W. L., Kenow, K. P. (1997): Effect of irradiance on growth and winter bud production by Vallisneria Americana and consequences to its abundance and distribution. - Aquatic Botany 58: 1-9.

[27] Kuriata-Potasznik, A., Szymczyk, S., Pilejczyk, D. (2018): Effect of bottom sediments on the nutrient and metal concentration in macrophytes of river-lake systems. - Annales de Limnologie - International Journal of Limnology 54: 1. 
[28] Kvet, J., Pokorny, J., Cizkova, H. (2008): Carbon accumulation by macrophytes of aquatic and wetland habitats with standing water. - Proceedings of the National Academy of Sciences India Section B, Biological Sciences 78: 91-98.

[29] Lee, S. H., Yun, M. S., Kim, B. K., Joo, H. T., Kang, S.-H., Kang, C. K., Whitledge, T. E. (2009): Contribution of small phytoplankton to total primary production in the Chukchi Sea. - Continental Shelf Research 68: 43-50.

[30] Lolu, A. J., Ahluwalia, A. S., Sidhu, M. C., Reshi, Z. A. (2018): Carbon sequestration potential of macrophytes and seasonal carbon input assessment into the Hokersar Wetland, Kashmir. - Wetlands 39: 453-472.

[31] Lone, P. A., Bhardwaj, A. K., Shah, K. W. T. (2014): Macrophytes as powerful natural tools for water quality improvement. - Research Journal of Botany 9: 24-30.

[32] Lv, L., Zhang, X., Qiao, J. (2018): Flocculation of low algae concentration water using polydiallyl dimethylammonium chloride coupled with polysilicate aluminum ferrite. Environmental Technology 39: 83-90.

[33] Maqbool, C., Khan, A. B. (2013): Biomass and carbon content of emergent macrophytes in Lake Manasbal, Kashmir: implications for carbon capture and sequestration. - International Journal of Scientific and Research Publications 3: 1-7.

[34] Mcleod, E., Chmura, G. L., Bouillon, S., Salm, R., Björk, M., Duarte, C. M., Lovelock, C. E., Schlesinger, W. H., Silliman, B. R. (2011): A blueprint for blue carbon: toward an improved understanding of the role of vegetated coastal habitats in sequestering $\mathrm{CO}_{2}$. - Frontiers in Ecology and the Environment 9(10): 552-560.

[35] Mellors, J. E. (1991): An evaluation of a rapid visual technique for estimating seagrass biomass. - Aquatic Botany 42(1): 67-73.

[36] Mohamed, Z. A. (2017): Macrophytes-cyanobacteria allelopathic interactions and their implications for water resources management - a review. - Limnologica 63: 122-132.

[37] Møller, C. L., Sand-Jensen, K. (2011): High sensitivity of Lobelia dortmanna to sediment oxygen depletion following organic enrichment. - New Phytologist 190(2): 320-331.

[38] Moss, R. H., Edmonds, J. A., Hibbard, K. A., Manning, M. R., Rose, S. K., Vuuren, D. P. V., Carter, T. R., Emori, S., Kainuma, M., Kram, T., Meehl, G. A., Mitchell, J. F. B., Nakicenovic, N., Riahi, K., Smith, S. J., Stouffer, R. J., Thomson, A. M., Weyant, J. P., Wilbanks, T. J. (2010): The next generation of scenarios for climate change research and assessment. - Article in Nature 463: 747-756.

[39] Penning, W. E., Mjelde, M., Dudley, B., Hellsten, S., Hanganu, J., Kolada, A., van den Berg, M., Poikane, S., Phillips, G., Willby, N., Ecke, F. (2008): Classifying aquatic macrophytes as indicators of eutrophication in European lakes. - Aquatic Ecology 42(2): 237-251.

[40] Pezeshki, S. R. (2001): Wetland plant responses to soil flooding. - Environmental and Experimental Botany 46: 299-312.

[41] Pongpiachan, S., Tipmanee, D., Choochuay, C., Hattayanone, M., Deelaman, W., Iadtem, N., Bunsomboonsakul, S., Palakun, J., Poshyachinda, S., Leckngam, A., Somboonpon, P., Panyaphirawat, T., Aukkaravittayapun, S., Wang, Q., Xing, L., Li, G., Han, Y., Cao, J. (2019): Vertical profile of organic and elemental carbon in sediments of Songkhla Lake, Thailand. - Limnology 20(2): 203-214.

[42] Pornpinatepong, K., Kiripat, S., Treewanchai, S., Chongwilaikasaem, S., Pornsawang, C., Chantarasap, P., Chandee, C., Jantrakul, P. (2010): Pollution control and sustainable fisheries management in Southern Songkhla Lake, Thailand. - Report No. 2010- RR5. Economy and Environment Program for Southeast Asia (EEPSEA). Singapore.

[43] Qiu, D., Wu, Z., Liu, B., Deng, J., Fu, G., He, F. (2001): The restoration of aquatic macrophytes for improving water quality in a hypertrophic shallow ake in Hubei Province, China. - Ecological Engineering 18(2): 147-156.

[44] Ralph, P. J., Gademann, R. (2005): Rapid light curves: a powerful tool to assess photosynthetic activity. - Aquatic Botany 82: 222-237. 
[45] Reitsema, R. E., Meire, P., Schoelynck, J. (2018): The future of freshwater macrophytes in a changing world: dissolved organic carbon quantity and quality and its interactions with macrophytes. - Frontiers in Plant Science 9: 629.

[46] Riis, T., Tank, J. L., Reisinger, A. J., Aubenau, A., Roche, K. R., Levi, P. S., Baattrup-Pedersen, A., Alnoee, A. B., Bolster, D. (2020): Riverine macrophytes control seasonal nutrient uptake via both physical and biological pathways. - Freshwater Biology 65(2): 178-192.

[47] Rojo, C., Segura, M., Rodrigo, M. A. (2013): The allelopathic capacity of submerged macrophytes shapes the microalgal assemblages from a recently restored coastal wetland. - Ecological Engineering 58: 149-155.

[48] Ruan, A. L., Borum, J., Sand-Jensen, K. (2010): Influence of sediment organic enrichment and water alkalinity on growth of aquatic isoetid and elodeid plants. Freshwater Biology 55: 1891-1904.

[49] Ritchie, R. J. (2006): Consistent sets of spectrophotometric chlorophyll equations for acetone, methanol and ethanol solvents. - Photosynthesis Research 89(1): 27-41.

[50] Sahu, Y. K., Deb, M. K., Patel, K. S., Martín-Ramos, P., Towett, E. K., TarkowskaKukuryk, M. (2020): Bioaccumulation of nutrients and toxic elements with macrophytes. - Journal of Hazardous, Toxic, and Radioactive Waste 24(1): 05019007.

[51] Sand-Jensen, K. (1997): Macrophytes as Biological Engineers in the Ecology of Danish Streams. - In: Sand-Jensen, K., Pedersen, O. (eds.) Freshwater Biology: Priorities and Development in Danish Research. The Freshwater Biological Laboratory, University of Copenhagen and G. E. C. Gad Publishers, Copenhagen.

[52] Sand-Jensen, K., Møller, C. L. (2014): Reduced root anchorage of freshwater plants in sandy sediments enriched with fine organic matter. - Freshwater Biology 59(3): 427437.

[53] Schneider, B., Cunha, E. R., Marchese, M., Thomaz, S. M. (2018): Associations between macrophyte life forms and environmental and morphometric factors in a large sub-tropical floodplain. - Frontiers in Plant Science 9: 1-8.

[54] Scholten, M. C., Foekema, E. M., Dokkum, H. P., Jak, R. G., Kaag, N. H. (2005): Eutrophication Management and Ecotoxicology. - Springer Science \& Business Media, Dordrecht.

[55] Schreiber, U. (2004): Pulse-Amplitude-Modulation (PAM) Fluorometry and Saturation Pulse Method: An Overview. - In: Papageorgiou G. C., Govindjee (eds.) Chlorophyll a Fluorescence. Advances in Photosynthesis and Respiration, Vol 19. Springer, Dordrecht.

[56] Schutten, J., Dainty, J., Davy, A. J. (2005): Root anchorage and its significance for submerged plants in shallow lakes. - Journal of Ecology 93: 556-591.

[57] Sheng, C., Azevedo, J. L. T. (2005): Estimating the higher heating value of biomass fuels from basic analysis data. - Biomass and Bioenergy 28: 499-507.

[58] Smith, V. H., Tilman, G. D., Nekola, J. C. (1999): Eutrophication: impacts of excess nutrient inputs on freshwater, marine, and terrestrial ecosystems. - Environmental Pollution 100: 179-196.

[59] Soana, E. (2012): Radial oxygen loss from roots of Vallisneria spiralis L.: biogeochemical implications in eutrophic aquatic ecosystems. - Ph.D. Thesis. University of Parma, Parma.

[60] Sompongchaiyakul, P., Sirinawin, W. (2007): Arsenic, chromium and mercury in surface sediment of Songkhla Lake, Thailand. - Asian Journal of Water, Environment and Pollution 4: 17-24.

[61] Sompongchaiyakul, P., Laongsiriwong, N., Sangkarnjanawanich, P. (2004): An occurrence of eutrophication in Songkhla Lake: a review. - In: Proceedings of the International Workshop on Integrated Lake Management, Hai-Yai, Songkhla, 19-21 August 2004, pp. 1-14. 
[62] Sousa, W. T. Z., Thomaz, S. M., Murphy, K. J. (2010): Response of native Egeria najas planch. and invasive Hydrilla verticillata (L. f.) Royle to altered hydroecological regime in a subtropical river. - Aquatic Botany 92: 40-48.

[63] Souza, G. M., Lüttge, U. (2015): Stability as a Phenomenon Emergent from PlasticityComplexity-Diversity in Eco-physiology. - In: Lüttge, U., Beyschlag, W. (eds) Progress in Botany 76. Springer, Cham, pp. 211-239.

[64] State of the Ocean. (2018): Sea surface temperature and wind speed in Kukud, Songkhla Lake area from May 2017 to May 2018. - https://podaactools.jpl.nasa.gov/soto/\#b=BlueMarble_ShadedRelief_Bathymetry\&l=GHRSST_L4_M UR_Sea_Surface_Temperature. May 2017-May 2018.

[65] Stefanidis, K., Sarika, M., Papastegiadou, E. (2019): Exploring environmental predictors of aquatic macrophytes in water-dependent Natura 2000 sites of high conservation value: results from a long-term study of macrophytes in Greek lakes. Aquatic Conservation: Marine and Freshwater Ecosystems 29(7): 1133-1148.

[66] Steffen, W., Richardson, K., Rockstrom, J., Cornell, S. E., Fetzer, I., Bennett, E. M., Biggs, R., Carpenter, S. R., de Vries, W., de Wit, C. A., Folke, C., Gerten, D., Heinke, J., Mace, G. M., Persson, L. M., Ramanathan, V., Reyers, B., Sorlin, S. (2015): Planetary boundaries: guiding human development on a changing planet. - Science 347: 736-855.

[67] Thongkao, S., Nintharakit, N., Pattanakiart, S. (2001): Pattern changes of aquatic plants in Ku Khud Lake (Songkhla) during 1988-1996: a remote sensing study. - In 5. BRT Annual Conference, Udon Thani (Thailand), 8-11 Oct 2001.

[68] Trevathan-Tackett, S. M., Kelleway, J., Macreadie, P. I., Beardall, J., Ralph, P., Bellgrove, A. (2015): Comparison of marine macrophytes for their contributions to blue carbon sequestration. - Ecology 96: 3043-3057.

[69] Vitousek, P. M., Aber, J. D., Howarth, R. W., Likens, G. E., Matson, P. A., Schindler, D. W., Schlesinger, W. H., Tilman, D. (1997a): Human alteration of the global nitrogen cycle: sources and consequences. - Ecological Applications 7: 737-750.

[70] Vitousek, P. M., Mooney, H. A., Lubchenco, J., Melillo, J. M. (1997b): Human domination of Earth's ecosystems. - Science 277: 494-499.

[71] Wang, C., Lu, J., Zhang, S., Wang, P., Hou, J., Qian, J. (2011): Effects of Pb stress on nutrient uptake and secondary metabolism in submerged macrophyte Vallisneria natans. - Ecotoxicology and Environmental Safety 74(5): 1297-1303.

[72] Wigand, C., Wehr, J. K., Limburg, B., Gorham, S., Longergan, S., Findlay, S. (2000): Effect of Vallisneria Americana (L.) on community structure and ecosystem function in lake mesocosms. - Hydrobiologia 418: 137-146.

[73] Yang, J. Q., Chen, J. H., Liu, J. J. (2008): A new genus and a new species of Braconinae (Hymenoptera, Braconidae) from China. - Acta Zootaxonomica Sinica 33: 61-64.

[74] Yasar, A., Farooq, T., Bari Tabinda, A., Tayyab Sohail, M., Mahfooz, Y., Malik, A. (2019): Macrophytes as potential indicator of heavy metals in river water. Desalination and Water Treatment 142: 272-278.

[75] Zhang, Q., Dong, B., Li, H., Liu, R., Luo, F., Zhang, M. (2012): Does light heterogeneity affect structure and biomass of submerged macrophyte communities? Botanical Studies 53(3): 377-385.

[76] Zhang, Q., Xu, Y. S., Huang, L., Xue, W., Sun, G. Q., Zhang, M. X. (2014): Does mechanical disturbance affect the performance and species composition of submerged macrophyte communities? - Scientific Reports 4: 1-6.

[77] Zhu, J., Liu, B., Wang, J., Gao, Y., Wu, Z. (2010): Study on the mechanism of allelopathic influence on cyanobacteria and chlorophytes by submerged macrophyte (Myriophyllum spicatum) and its secretion. - Aquatic Toxicology 98(2): 196-203. 


\section{APPENDIX}

Table A1. Presence (x) of 8 species including free floating macrophytes (Salvinia cucullata), submerged macrophytes (Ceratophyllum demersum, Elodea canadensis, Najas marina, Potamogeton malaianus, Chara zeylanica and Najas graminea) and macroalgae (Cladophora sp.) for each site in Kukud, Songkhla Lagoon area from May 2017 to May 2018

\begin{tabular}{|c|c|c|c|c|c|c|c|c|c|c|c|c|c|c|c|c|c|c|}
\hline \multirow[b]{2}{*}{ Species } & \multicolumn{6}{|c|}{ Site 1} & \multicolumn{6}{|c|}{ Site 2} & \multicolumn{6}{|c|}{ Site 3} \\
\hline & $\frac{1}{3}$ & $\frac{5}{3}$ & 气 & $\frac{\infty}{10}$ & $\frac{\infty}{\dot{\pi}}$ & 离 & 紊 & $\frac{5}{\Xi}$ & $\frac{5}{5}$ & $\frac{\infty}{10}$ & $\frac{\infty}{\dot{\pi}}$ & 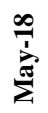 & 紊 & $\frac{5}{3}$ & 部 & $\frac{\infty}{10}$ & $\stackrel{\infty}{\stackrel{5}{\pi}}$ & $\stackrel{\infty}{\frac{1}{2}}$ \\
\hline $\begin{array}{l}\text { Cladophora sp. } \\
\text { Ceratophyllum } \\
\text { demersum }\end{array}$ & $\mathrm{x}$ & $\mathrm{x}$ & $\mathrm{x}$ & & & & $\mathrm{x}$ & $\mathrm{x}$ & $\mathrm{x}$ & & & $\mathrm{x}$ & & $\mathrm{x}$ & $\mathrm{x}$ & & & \\
\hline $\begin{array}{c}\text { Salvinia cucullata } \\
\text { Potamogeton }\end{array}$ & $\mathrm{x}$ & $\mathrm{x}$ & & & & & & & & & & & & & & & & \\
\hline $\begin{array}{c}\text { malaianus } \\
\text { Najas marina }\end{array}$ & & & & & & & $\mathrm{X}$ & $\mathrm{x}$ & $\mathrm{x}$ & & & $\begin{array}{l}\mathrm{x} \\
\mathrm{x}\end{array}$ & $\begin{array}{l}\mathrm{x} \\
\mathrm{x}\end{array}$ & $\begin{array}{l}\mathrm{x} \\
\mathrm{x}\end{array}$ & $\mathrm{x}$ & $\mathrm{X}$ & $\mathrm{x}$ & $\mathrm{x}$ \\
\hline Najas graminea & & & & & & & $\mathrm{x}$ & $\mathrm{x}$ & & & & & $\mathrm{x}$ & $\mathrm{x}$ & $\mathrm{x}$ & & & \\
\hline $\begin{array}{c}\text { Chara zeylanica } \\
\text { Elodea } \\
\text { canadensis }\end{array}$ & & & & & & & $\mathrm{x}$ & $\mathrm{x}$ & $\mathrm{x}$ & & $\mathrm{x}$ & $\mathrm{x}$ & $\mathrm{x}$ & $\begin{array}{l}\mathrm{x} \\
\mathrm{x}\end{array}$ & $\begin{array}{l}\mathrm{x} \\
\mathrm{x}\end{array}$ & $\mathrm{x}$ & $\mathrm{x}$ & $\mathrm{x}$ \\
\hline
\end{tabular}

Table A2. Two-Way ANOVA showed significant differences (*) among time, site, and site*time in percentage cover of 8 species including free floating macrophytes (Salvinia cucullata), submerged macrophytes (Ceratophyllum demersum, Elodea Canadensis, Najas marina, Potamogeton malaianus, Chara zeylanica and Najas graminea) and macroalgae (Cladophora sp.), water quality, and sediment characteristics in Kukud, Songkhla Lagoon area from May 2017 to May 2018

\begin{tabular}{|c|c|c|c|c|c|c|c|c|c|}
\hline & \multicolumn{3}{|c|}{ Time } & \multicolumn{3}{|c|}{ Site } & \multicolumn{3}{|c|}{ Time*site } \\
\hline & $d f$ & $F$ & sig & $d f$ & $F$ & sig & $d f$ & $F$ & sig \\
\hline Percentage cover & & & & & & & & & \\
\hline Ceratophyllum demersum & 5 & 200.066 & $<0.001 *$ & 2 & 547.783 & $<0.001^{*}$ & 10 & 172.047 & $<0.001^{*}$ \\
\hline Potamogeton malaianus & 5 & 212.102 & $<0.001 *$ & 2 & 2720.078 & $<0.001^{*}$ & 10 & 190.661 & $<0.001 *$ \\
\hline Najas marina & 5 & 87.162 & $<0.001 *$ & 2 & 122.119 & $<0.001 *$ & 10 & 83.320 & $<0.001 *$ \\
\hline Najas graminea & 5 & 839.550 & $<0.001 *$ & 2 & 844.200 & $<0.001 *$ & 10 & 299.550 & $<0.001 *$ \\
\hline Chara zeylanica & 5 & 791.210 & $<0.001 *$ & 2 & 3015.267 & $<0.001^{*}$ & 10 & 594.662 & $<0.001^{*}$ \\
\hline Elodea Canadensis & 5 & 20.558 & $<0.001 *$ & 2 & 299.129 & $<0.001 *$ & 10 & 20.558 & $<0.001 *$ \\
\hline Salvinia cucullata & 5 & 22.000 & $<0.001 *$ & 2 & 40.000 & $<0.001 *$ & 10 & 22.000 & $<0.001 *$ \\
\hline Cladophora sp. & 5 & 1346.571 & $<0.001 *$ & 2 & 3375.536 & $<0.001 *$ & 10 & 749.893 & $<0.001 *$ \\
\hline Water quality & & & & & & & & & \\
\hline Temperature & 5 & 1981.010 & $<0.001 *$ & 2 & 880.026 & $<0.001^{*}$ & 10 & 49.287 & $<0.001 *$ \\
\hline Salinity & 5 & 778315.700 & $<0.001 *$ & 2 & 12060.500 & $<0.001 *$ & 10 & 5375.900 & $<0.001 *$ \\
\hline DO & 5 & 146.741 & $<0.001 *$ & 2 & 3864.699 & $<0.001^{*}$ & 10 & 257.338 & $<0.001 *$ \\
\hline Conductivity & 5 & 134619.463 & $<0.001 *$ & 2 & 1220.529 & $<0.001 *$ & 10 & 4934.839 & $<0.001 *$ \\
\hline TDS & 5 & 5218393.498 & $<0.001 *$ & 2 & 25363.744 & $<0.001 *$ & 10 & 75124.303 & $<0.001 *$ \\
\hline $\mathrm{pH}$ & 5 & 2327.978 & $<0.001 *$ & 2 & 3530.389 & $<0.001 *$ & 10 & 430.549 & $<0.001 *$ \\
\hline Depth & 5 & 597.082 & $<0.001 *$ & 2 & 2331.330 & $<0.001^{*}$ & 10 & 46.673 & $<0.001 *$ \\
\hline Secchi Depth & 5 & 531.581 & $<0.001 *$ & 2 & 229.586 & $<0.001 *$ & 10 & 137.414 & $<0.001 *$ \\
\hline Nitrate & 5 & 5.045 & $0.001^{*}$ & 2 & 2.907 & 0.068 & 10 & 0.993 & 0.467 \\
\hline Phosphate & 5 & 74.949 & $<0.001 *$ & 2 & 6.969 & $0.003^{*}$ & 10 & 16.345 & $<0.001 *$ \\
\hline Chlorophyll $a$ & 5 & 15.600 & $<0.001 *$ & 2 & 46.456 & $<0.001 *$ & 10 & 6.217 & $<0.001 *$ \\
\hline Organic matter & 5 & 43.852 & $<0.001 *$ & 2 & 45.714 & $<0.001 *$ & 10 & 12.012 & $<0.001 *$ \\
\hline Organic carbon & 5 & 43.852 & $<0.001 *$ & 2 & 45.714 & $<0.001^{*}$ & 10 & 12.012 & $<0.001^{*}$ \\
\hline Sediment characteristics & & & & & & & & & \\
\hline Carbon & 5 & 608.693 & $<0.001 *$ & 2 & 3720.636 & $<0.001 *$ & 10 & 343.078 & $<0.001 *$ \\
\hline Nitrogen & 5 & 1471.328 & $<0.001 *$ & 2 & 4150.365 & $<0.001 *$ & 10 & 521.708 & $<0.001^{*}$ \\
\hline Carbon:Nitrogen ratios & 5 & 42.141 & $<0.001 *$ & 2 & 232.473 & $<0.001^{*}$ & 10 & 9.843 & $<0.001^{*}$ \\
\hline
\end{tabular}

*Significant difference 
Table A3. Two-Way ANOVA showed significant differences (*) among time, site, and site*time in leaf length, leaf dry weight, organic matter, organic carbon, $H H V_{\text {ult, }} H H V_{\text {prox }}$, EQY, ETR, $I_{k}$, and Alpha of 6 submerged macrophytes species in Kukud, Songkhla Lagoon area from May 2017 to May 2018

\begin{tabular}{|c|c|c|c|c|c|c|c|c|c|c|c|c|c|c|c|c|c|c|}
\hline & \multicolumn{3}{|c|}{$\begin{array}{l}\text { Ceratophyllum } \\
\text { demersum }\end{array}$} & \multicolumn{3}{|c|}{$\begin{array}{l}\text { Potamogeton } \\
\text { malaianus }\end{array}$} & \multicolumn{3}{|c|}{ Najas marina } & \multicolumn{3}{|c|}{ Najas graminea } & \multicolumn{3}{|c|}{ Chara zeylanica } & \multicolumn{3}{|c|}{ Elodea canadensis } \\
\hline & $d f$ & $F$ & $p$ & $d f$ & $F$ & $p$ & $d f$ & $F$ & $p$ & $d f$ & $F$ & $p$ & $d f$ & $F$ & $p$ & $d f$ & $F$ & $p$ \\
\hline \multicolumn{19}{|l|}{ Time } \\
\hline Leaf length & 2 & 8.214 & $0.002 *$ & 5 & 23.277 & $<0.001^{*}$ & 3 & 0.574 & 0.638 & 2 & 45.273 & $<0.001 *$ & 3 & 3.949 & $0.018 *$ & 4 & 2.175 & 0.102 \\
\hline $\begin{array}{l}\text { Leaf dry } \\
\text { weight }\end{array}$ & 2 & 127.980 & $<0.001 *$ & 5 & 6.936 & $<0.001^{*}$ & 3 & 0.721 & 0.549 & 2 & 351.834 & $<0.001 *$ & 3 & 0.283 & 0.837 & 4 & 0.640 & 0.639 \\
\hline Organic matter & 2 & 24.014 & $<0.001 *$ & 5 & 21.667 & $<0.001 *$ & 3 & 2.032 & 0.163 & 2 & 176.247 & $<0.001 *$ & 3 & 12.588 & $<0.001 *$ & 4 & 3.802 & $0.032 *$ \\
\hline Organic carbon & 2 & 24.014 & $<0.001 *$ & 5 & 21.667 & $<0.001 *$ & 3 & 2.032 & 0.163 & 2 & 176.247 & $<0.001 *$ & 3 & 12.588 & $<0.001 *$ & 4 & 3.802 & $0.032 *$ \\
\hline $\mathrm{HHV}_{\text {ult }}$ & 2 & 24.014 & $<0.001 *$ & 5 & 21.667 & $<0.001 *$ & 3 & 2.032 & 0.163 & 2 & 176.247 & $<0.001 *$ & 3 & 12.588 & $<0.001 *$ & 4 & 3.802 & $0.032 *$ \\
\hline $\mathrm{HHV}_{\text {prox }}$ & 2 & 24.014 & $<0.001 *$ & 5 & 21.667 & $<0.001 *$ & 3 & 2.032 & 0.163 & 2 & 176.247 & $<0.001 *$ & 3 & 12.588 & $<0.001 *$ & 4 & 3.802 & $0.032 *$ \\
\hline EQY & 2 & 1.973 & 0.174 & 5 & 1.743 & 0.155 & 3 & 2.532 & 0.090 & 2 & 1.688 & 0.218 & 3 & 3.141 & $0.047 *$ & 4 & 1.639 & 0.208 \\
\hline ETR & 2 & 1.028 & 0.381 & 5 & 4.035 & $0.006^{*}$ & 3 & 5.727 & $0.006^{*}$ & 2 & 0.564 & 0.581 & 3 & 3.141 & $0.047 *$ & 4 & 3.944 & $0.018^{*}$ \\
\hline $\mathrm{I}_{\mathrm{k}}$ & 2 & 3.592 & 0.053 & 5 & .865 & 0.516 & 3 & 0.240 & 0.867 & 2 & 0.159 & 0.854 & 3 & 1.134 & 0.358 & 4 & 1.721 & 0.189 \\
\hline Alpha & 2 & 7.475 & $0.006^{*}$ & 5 & 7.306 & $<0.001^{*}$ & 3 & 1.764 & 0.190 & 2 & 0.147 & 0.864 & 3 & 2.933 & 0.057 & 4 & 1.886 & 0.157 \\
\hline \multicolumn{19}{|l|}{ Site } \\
\hline Leaf length & 1 & 71.643 & $<0.001^{*}$ & 1 & 0.068 & 0.795 & 1 & 1.292 & 0.267 & 1 & 2.563 & 0.125 & 1 & 0.228 & 0.636 & 1 & 3.253 & 0.084 \\
\hline $\begin{array}{c}\text { Leaf dry } \\
\text { weight }\end{array}$ & 1 & 5.960 & $0.024 *$ & 1 & 0.022 & 0.884 & 1 & 13.988 & $0.001^{*}$ & 1 & 197.881 & $<0.001 *$ & 1 & 1.492 & 0.232 & 1 & 0.400 & 0.533 \\
\hline Organic matter & 1 & 12.969 & $0.005 *$ & 1 & 2.330 & 0.143 & 1 & 55.222 & $<0.001^{*}$ & 1 & 122.047 & $<0.001 *$ & 1 & 19.194 & $0.001 *$ & 1 & 2.167 & 0.167 \\
\hline Organic carbon & 1 & 12.969 & $0.005^{*}$ & 1 & 2.330 & 0.143 & 1 & 55.222 & $<0.001^{*}$ & 1 & 122.047 & $<0.001 *$ & 1 & 19.194 & $0.001 *$ & 1 & 2.167 & 0.167 \\
\hline $\mathrm{HHV}_{\text {ult }}$ & 1 & 12.969 & $0.005^{*}$ & 1 & 2.330 & 0.143 & 1 & 55.222 & $<0.001 *$ & 1 & 122.047 & $<0.001 *$ & 1 & 19.194 & $0.001 *$ & 1 & 2.167 & 0.167 \\
\hline $\mathrm{HHV}_{\text {prox }}$ & 1 & 12.969 & $0.005^{*}$ & 1 & 2.330 & 0.143 & 1 & 55.222 & $<0.001 *$ & 1 & 122.047 & $<0.001 *$ & 1 & 19.194 & $0.001 *$ & 1 & 2.167 & 0.167 \\
\hline EQY & 1 & 21.297 & $<0.001 *$ & 1 & 0.237 & 0.630 & 1 & 2.822 & 0.110 & 1 & 1.464 & 0.245 & 1 & 7.508 & $0.012 *$ & 1 & 0.272 & 0.608 \\
\hline ETR & 1 & 1.850 & 0.194 & 1 & 1.419 & 0.243 & 1 & 3.541 & 0.076 & 1 & 0.470 & 0.504 & 1 & 4.398 & $0.048 *$ & 1 & 0.005 & 0.943 \\
\hline $\mathrm{I}_{\mathrm{k}}$ & 1 & 0.330 & 0.574 & 1 & 2.940 & 0.097 & 1 & 10.083 & $0.005^{*}$ & 1 & 0.221 & 0.645 & 1 & 0.273 & 0.607 & 1 & 0.406 & 0.532 \\
\hline Alpha & 1 & 4.942 & $0.042 *$ & 1 & 0.726 & 0.401 & 1 & 3.321 & 0.085 & 1 & 0.010 & 0.922 & 1 & 3.657 & 0.070 & 1 & 0.654 & 0.429 \\
\hline \multicolumn{19}{|l|}{ Time*site } \\
\hline Leaf length & 1 & 0.116 & 0.737 & 3 & 0.320 & 0.811 & 1 & 1.006 & 0.326 & 1 & 6.122 & $0.022 *$ & 2 & 0.260 & 0.773 & 0 & - & - \\
\hline $\begin{array}{l}\text { Leaf dry } \\
\text { weight }\end{array}$ & 1 & 66.225 & $<0.001 *$ & 3 & 0.070 & 0.976 & 1 & .236 & 0.631 & 1 & 9.535 & $0.006^{*}$ & 2 & 0.653 & 0.528 & 0 & - & - \\
\hline Organic matter & 1 & 13.642 & $0.004 *$ & 3 & 2.751 & 0.070 & 1 & 8.846 & $0.012^{*}$ & 1 & 0.020 & 0.889 & 2 & 3.245 & 0.070 & 0 & - & - \\
\hline Organic carbon & 1 & 13.642 & $0.004 *$ & 3 & 2.751 & 0.070 & 1 & 8.846 & $0.012^{*}$ & 1 & 0.020 & 0.889 & 2 & 3.245 & 0.070 & 0 & - & - \\
\hline $\mathrm{HHV}_{\text {ult }}$ & 1 & 13.642 & $0.004 *$ & 3 & 2.751 & 0.070 & 1 & 8.846 & $0.012^{*}$ & 1 & 0.020 & 0.889 & 2 & 3.245 & 0.070 & 0 & - & - \\
\hline $\mathrm{HHV}_{\text {prox }}$ & 1 & 13.642 & $0.004 *$ & 3 & 2.751 & 0.070 & 1 & 8.846 & $0.012^{*}$ & 1 & 0.020 & 0.889 & 2 & 3.245 & 0.070 & 0 & - & - \\
\hline EQY & 1 & 0.169 & 0.687 & 3 & 0.106 & 0.956 & 1 & 7.979 & $0.011^{*}$ & 1 & 0.226 & 0.641 & 2 & 4.275 & $0.028 *$ & 0 & - & - \\
\hline ETR & 1 & 0.190 & 0.669 & 3 & 0.809 & 0.499 & 1 & 0.004 & 0.952 & 1 & 0.498 & 0.491 & 2 & 5.734 & $0.010 *$ & 0 & - & - \\
\hline $\mathrm{I}_{\mathrm{k}}$ & 1 & 7.077 & $0.018 *$ & 3 & 0.975 & 0.418 & 1 & 0.018 & 0.896 & 1 & 0.020 & 0.890 & 2 & 4.697 & $0.021 *$ & 0 & - & - \\
\hline Alpha & 1 & 5.940 & $0.028 *$ & 3 & 0.667 & 0.579 & 1 & 0.264 & 0.614 & 1 & 0.526 & 0.479 & 2 & 2.594 & 0.098 & 0 & - & - \\
\hline
\end{tabular}




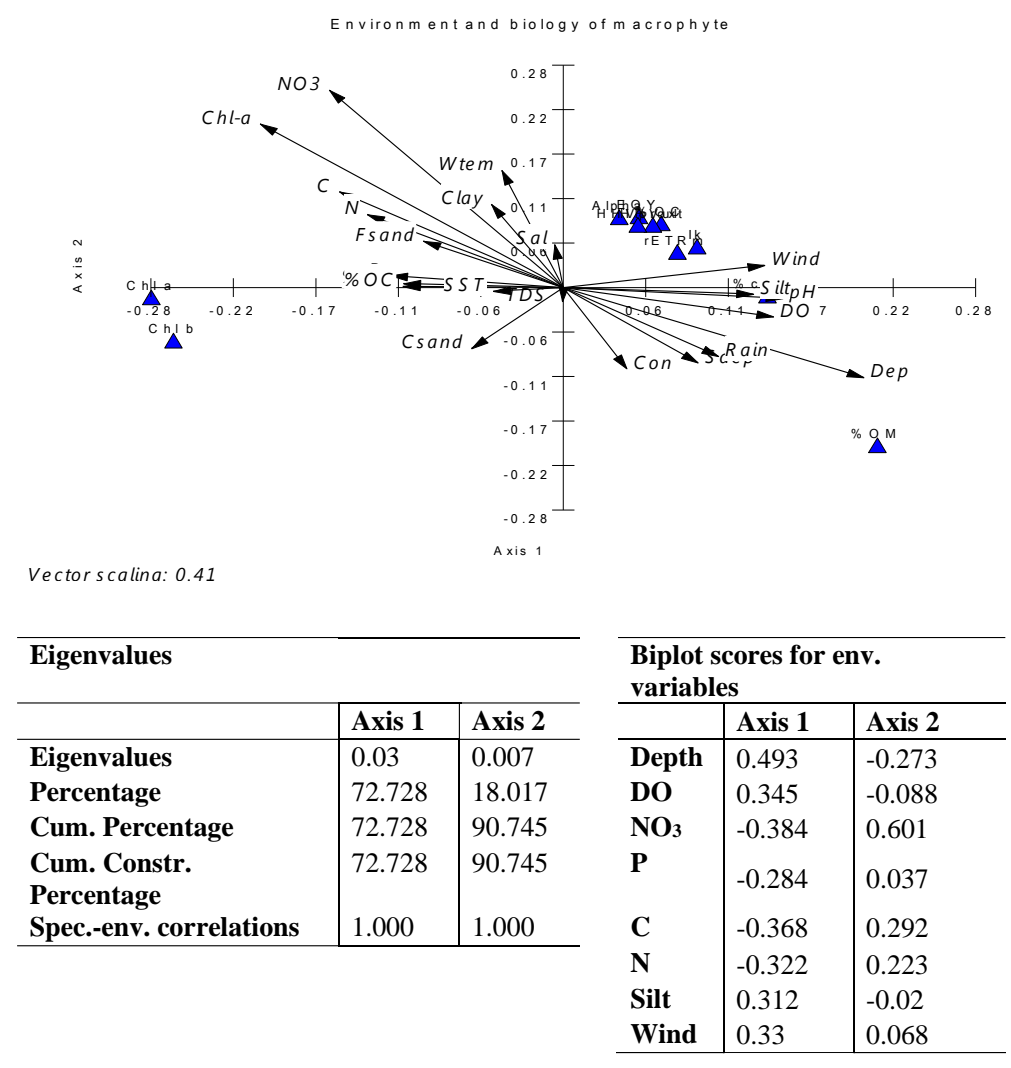

Figure A1. Relationships among environmental parameters and biology of submerged macrophytes in Kukud, Songkhla Lagoon area from May 2017 to May 2018

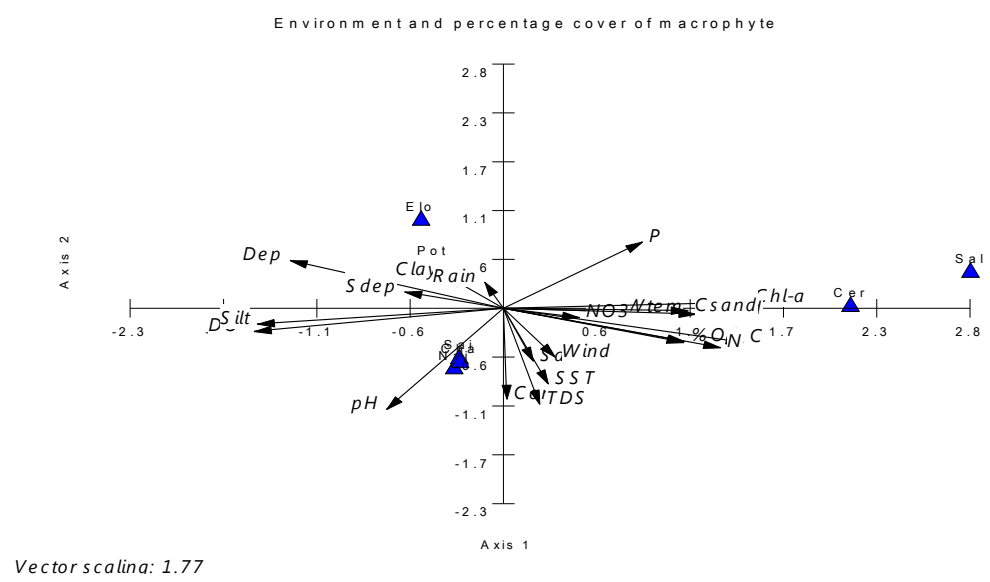

\begin{tabular}{l|l|l}
\hline Eigenvalues & Axis 1 & Axis 2 \\
\hline Eigenvalues & 0.823 & 0.392 \\
Percentage & 56.871 & 27.067 \\
Cum. Percentage & 56.871 & 83.939 \\
Cum.Constr.Percentage & 56.871 & 83.939 \\
Spec.-env. correlations & 1.000 & 1.000 \\
\hline
\end{tabular}

\begin{tabular}{l|l|l}
\hline \multicolumn{3}{l}{ Biplot scores for env. variables } \\
\hline & Axis 1 & Axis 2 \\
\hline Depth & -0.734 & 0.315 \\
DO & -0.858 & -0.151 \\
\% OM & 0.619 & -0.224 \\
\% OC & 0.622 & -0.217 \\
C & 0.823 & -0.223 \\
N & 0.745 & -0.257 \\
Silt & -0.847 & -0.103 \\
Fsand & 0.661 & -0.037
\end{tabular}

Figure A2. Relationship among environmental parameters and percentage cover of submerged macrophytes in Kukud, Songkhla Lake area from May 2017 to May 2018 


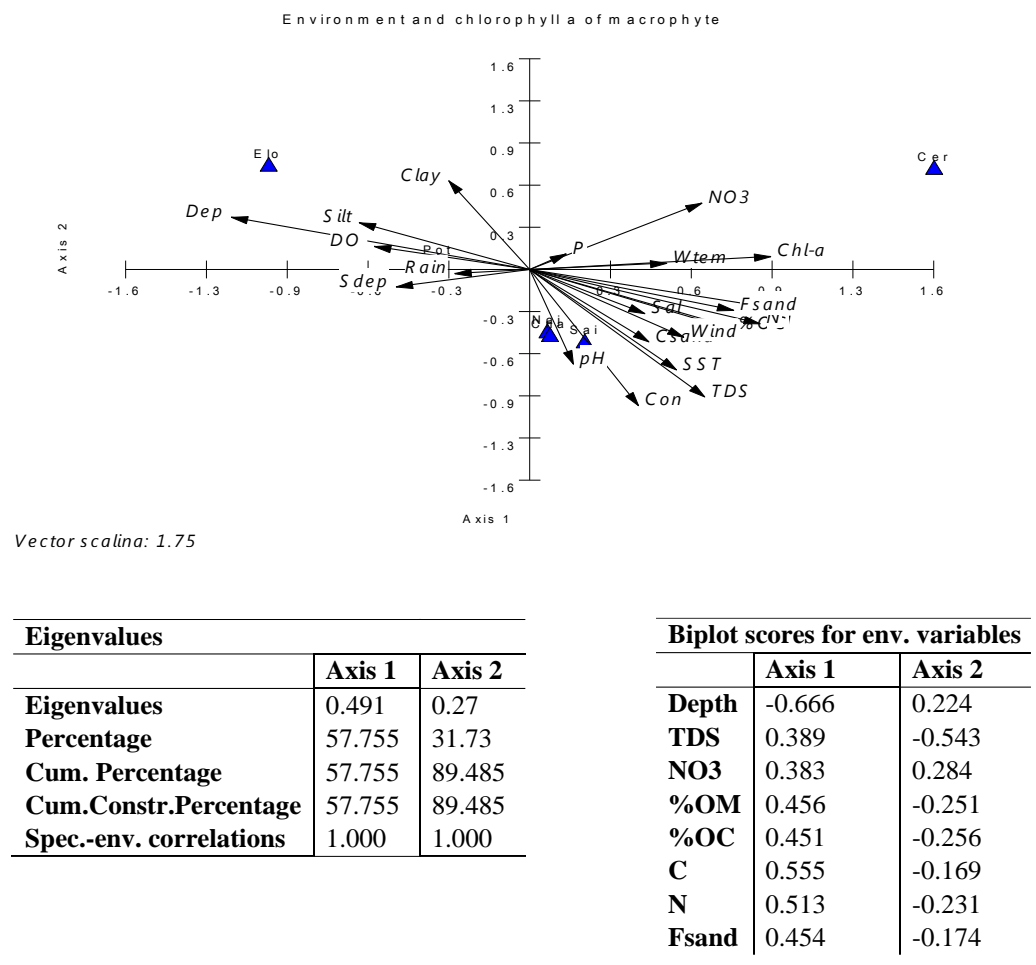

Figure A3. Relationship among environmental parameters and chlorophyll a content of submerged macrophytes in Kukud, Songkhla Lake area from May 2017 to May 2018

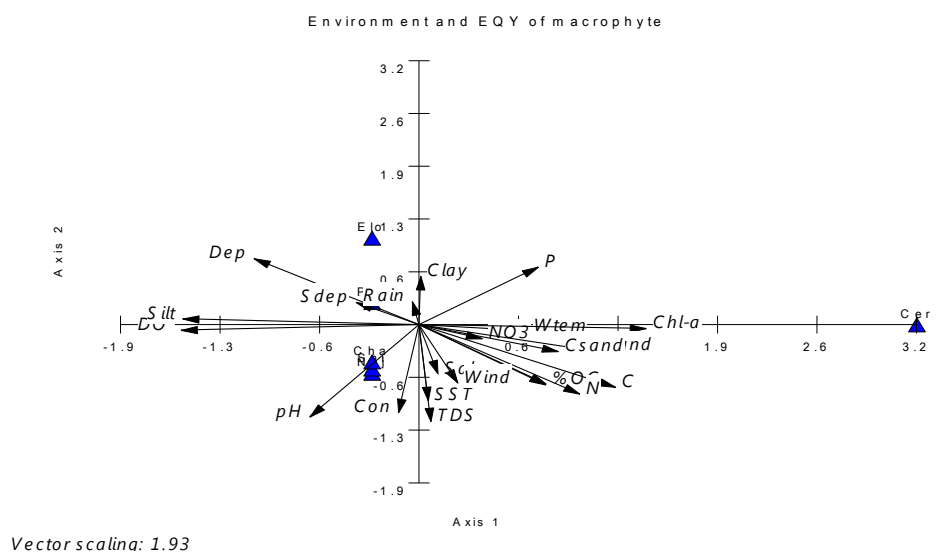

\begin{tabular}{|c|c|c|}
\hline \multicolumn{3}{|l|}{ Eigenvalues } \\
\hline & Axis 1 & Axis 2 \\
\hline Eigenvalues & 1.000 & 0.35 \\
\hline Percentage & 68.557 & 23.978 \\
\hline Cum. Percentage & 68.557 & 92.535 \\
\hline Cum.Constr.Percentage & 68.557 & 92.535 \\
\hline Spec.-env. correlations & 1.000 & 1.000 \\
\hline
\end{tabular}

\begin{tabular}{l|l|l}
\hline \multicolumn{3}{l}{ Biplot scores for env. variables } \\
\hline & Axis 1 & Axis 2 \\
\hline Depth & -0.56 & 0.423 \\
NO3 & 0.213 & -0.089 \\
P & 0.403 & 0.369 \\
Chl-a & 0.769 & -0.025 \\
\%OM & 0.428 & -0.384 \\
\%OC & 0.429 & -0.378 \\
C & 0.664 & -0.398 \\
N & 0.543 & -0.442 \\
Silt & -0.801 & 0.037
\end{tabular}

Figure A4. Relationship among environmental parameters and photosynthetic efficiency (Effective quantum yield of PSII) of submerged macrophytes in Kukud, Songkhla Lake area from May 2017 to May 2018 


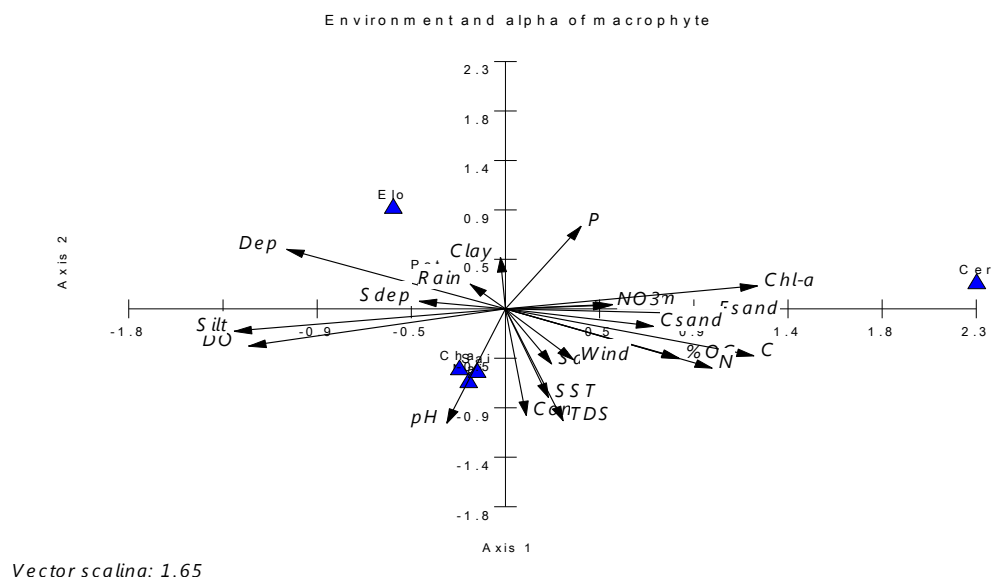

\begin{tabular}{|c|c|c|}
\hline \multicolumn{3}{|l|}{ Eigenvalues } \\
\hline & Axis 1 & Axis 2 \\
\hline Eigenvalues & 0.729 & 0.353 \\
\hline Percentage & 59.18 & 28.697 \\
\hline Cum. Percentage & 59.18 & 87.877 \\
\hline Cum.Constr.Percentage & 59.18 & 87.877 \\
\hline Spec.-env. correlations & 1.000 & 1.000 \\
\hline
\end{tabular}

\begin{tabular}{l|l|l}
\hline \multicolumn{3}{c}{ Biplot scores for env. variables } \\
\hline & Axis 1 & Axis 2 \\
\hline Depth & -0.644 & 0.334 \\
NO3 & 0.307 & 0.02 \\
P & 0.222 & 0.463 \\
Chl-a & 0.739 & 0.13 \\
\%OM & 0.509 & -0.278 \\
\%OC & 0.508 & -0.274 \\
C & 0.729 & -0.262 \\
N & 0.606 & -0.33 \\
Silt & -0.798 & -0.124
\end{tabular}

Figure A5. Relationship among environmental parameters and alpha of submerged macrophytes in Kukud, Songkhla Lake area from May 2017 to May 2018

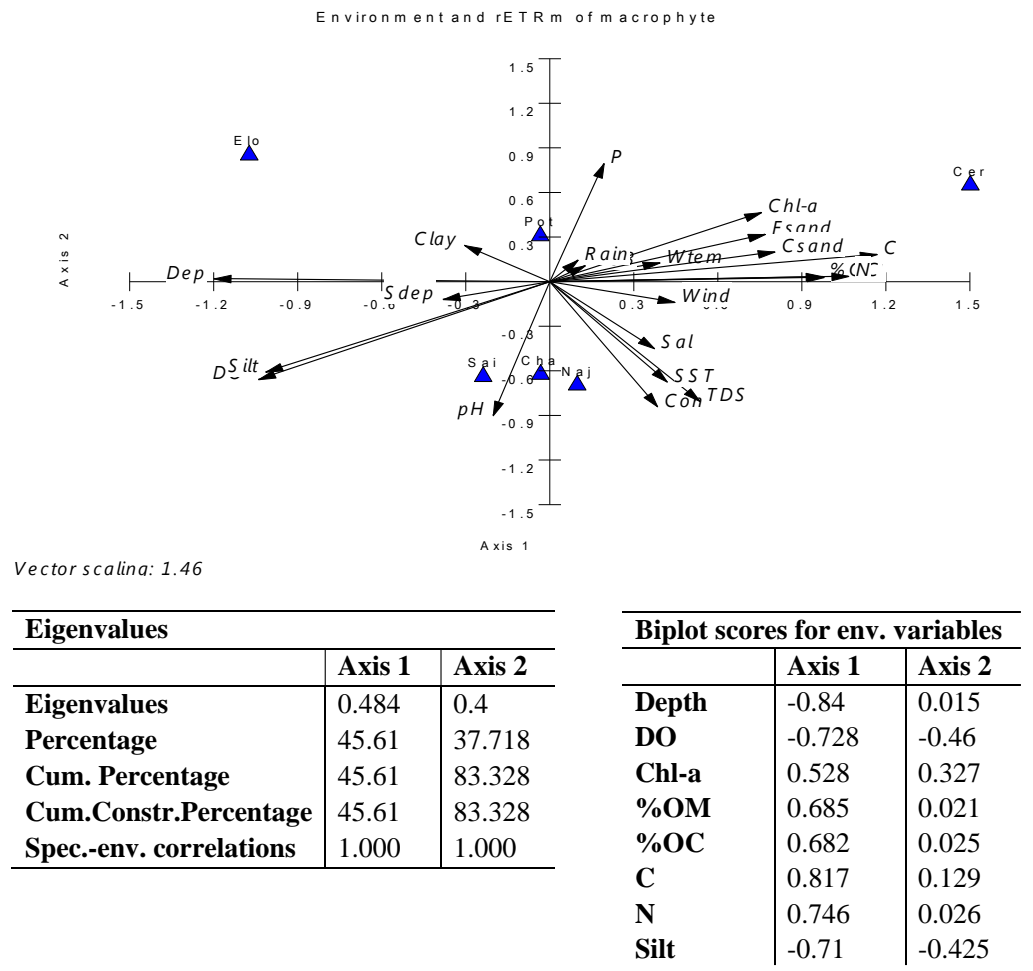

Figure A6. Relationship among environmental parameters and maximum relative electron transport rate of submerged macrophytes in Kukud, Songkhla Lake area from May 2017 to May 2018 


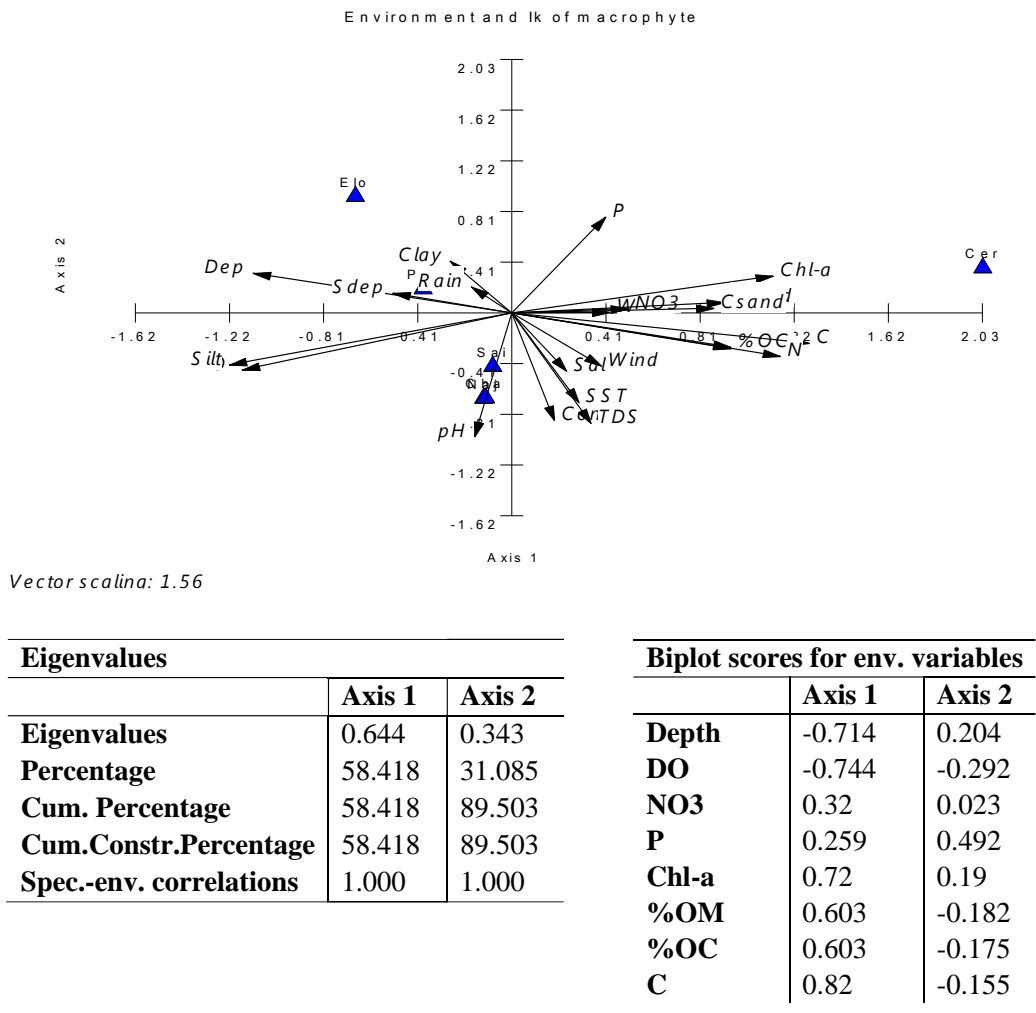

Figure A7. Relationship among environmental parameters and saturating irradiance of submerged macrophytes in Kukud, Songkhla Lake area from May 2017 to May 2018

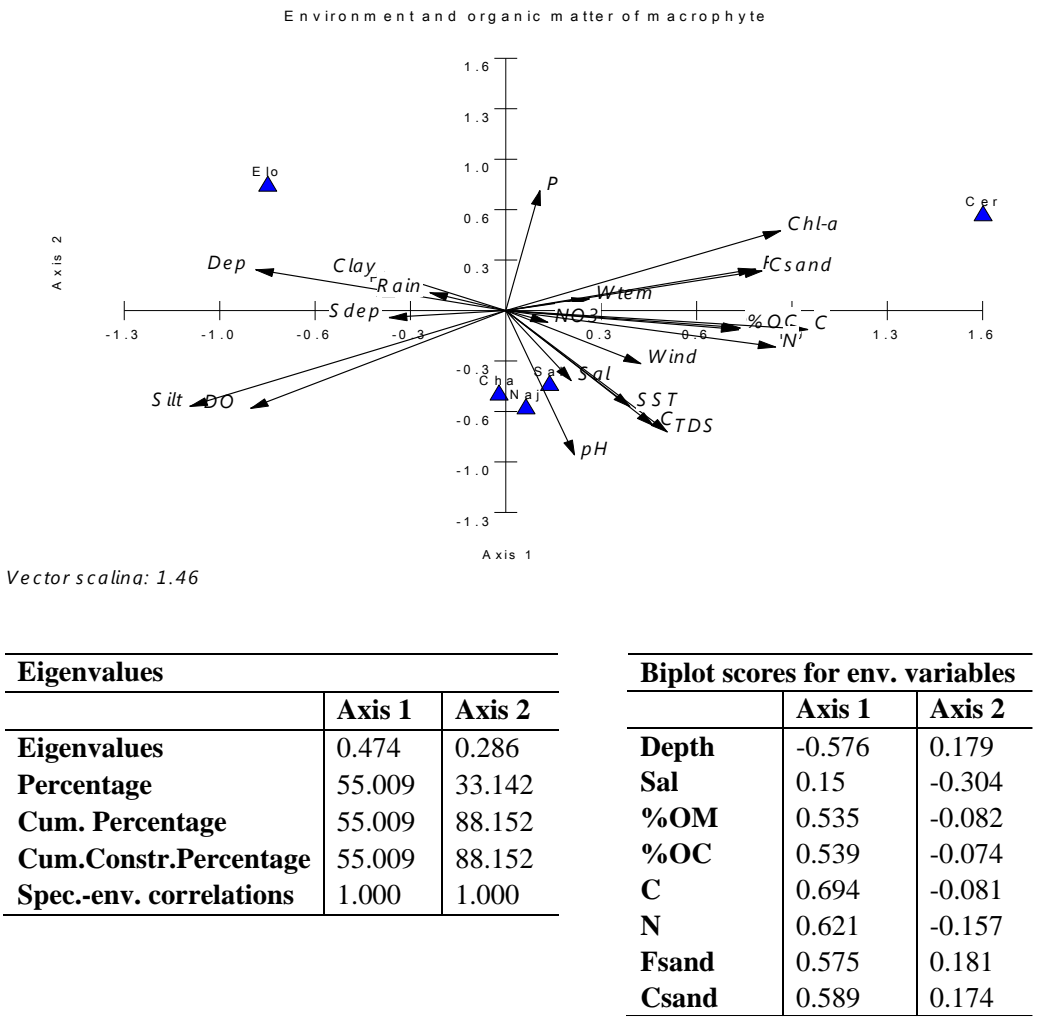

Figure A8. Relationship among environmental parameters and organic matter of submerged macrophytes in Kukud, Songkhla Lake area from May 2017 to May 2018 


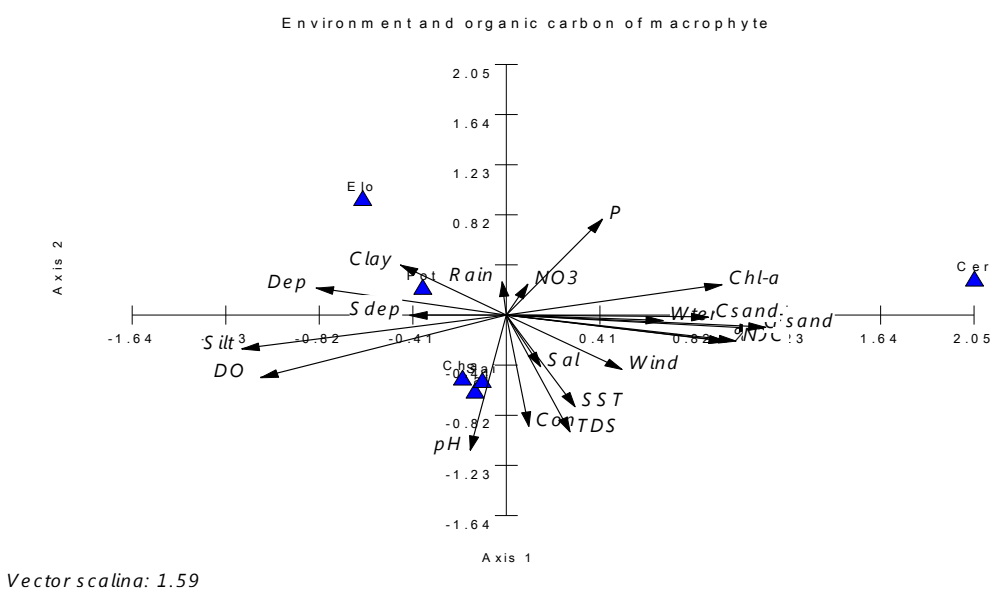

\begin{tabular}{l|l|l}
\hline Eigenvalues & Axis 1 & Axis 2 \\
\hline Eigenvalues & 0.647 & 0.308 \\
Percentage & 61.023 & 29.054 \\
Cum. Percentage & 61.023 & 90.077 \\
Cum.Constr.Percentage & 61.023 & 90.077 \\
Spec.-env. correlations & 1.000 & 1.000 \\
\hline
\end{tabular}

\begin{tabular}{l|l|l}
\hline \multicolumn{3}{c}{ Biplot scores for env. variables } \\
\hline & Axis 1 & Axis 2 \\
\hline Depth & -0.524 & 0.14 \\
Clay & -0.292 & 0.258 \\
pH & -0.1 & -0.693 \\
Sdep & -0.266 & 0 \\
\% OM & 0.604 & -0.135 \\
\% OC & 0.604 & -0.133 \\
C & 0.688 & -0.069 \\
N & 0.631 & -0.132 \\
\hline
\end{tabular}

Figure A9. Relationship among environmental parameters and organic carbon of submerged macrophytes in Kukud, Songkhla Lake area from May 2017 to May 2018

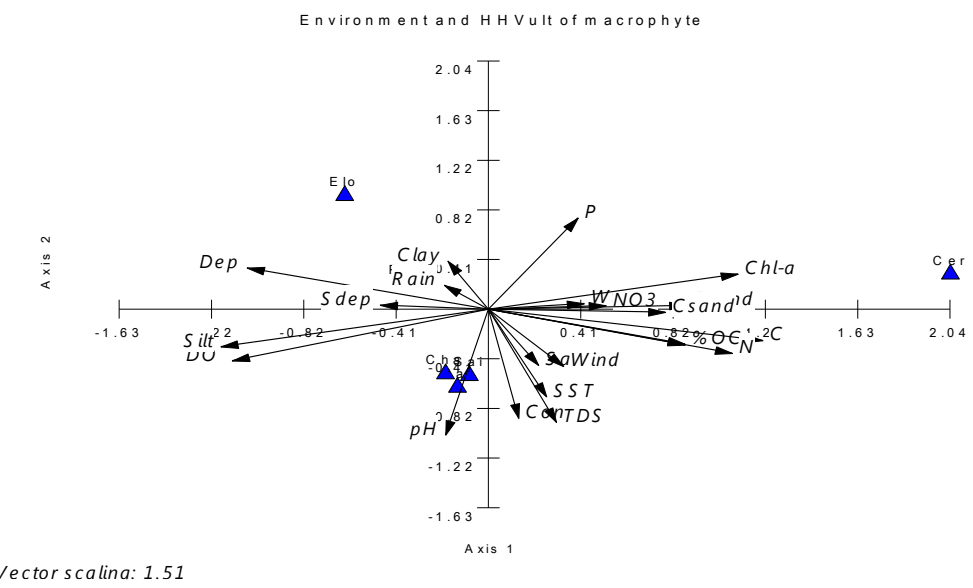

\begin{tabular}{l|l|l}
\hline Eigenvalues & Axis 1 & Axis 2 \\
\hline & 0.645 & 0.308 \\
Eigenvalues & 60.988 & 29.109 \\
Percentage & 60.988 & 90.097 \\
Cum. Percentage & 60.988 & 90.097 \\
Spec.-env. correlations & 1.000 & 1.000 \\
\hline
\end{tabular}

\begin{tabular}{l|l|l}
\hline \multicolumn{3}{c}{ Biplot scores for env. variables } \\
\hline & Axis 1 & Axis 2 \\
\hline Depth & -0.705 & 0.224 \\
Sdep & -0.317 & 0.023 \\
Chl-a & 0.728 & 0.191 \\
DO & -0.749 & -0.28 \\
NO3 & 0.343 & 0.02 \\
\%OM & 0.573 & -0.193 \\
\%OC & 0.573 & -0.188 \\
Silt & -0.782 & -0.204
\end{tabular}

Figure A10. Relationship among environmental parameters and HHVult of submerged macrophytes in Kukud, Songkhla Lake area from May 2017 to May 2018 


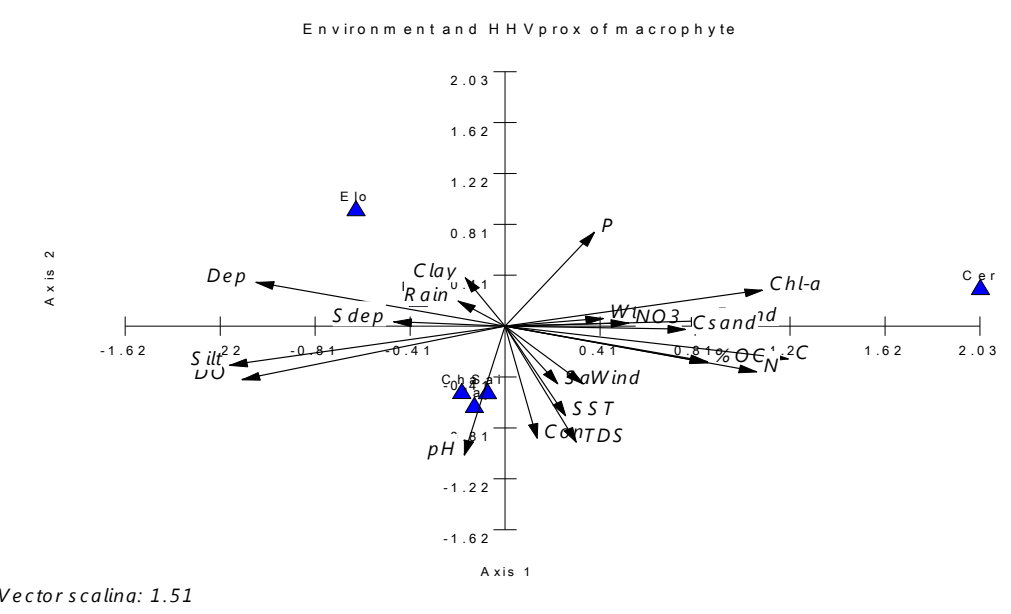

\begin{tabular}{|c|c|c|}
\hline \multicolumn{3}{|l|}{ Eigenvalues } \\
\hline & Axis 1 & Axis 2 \\
\hline Eigenvalues & 0.643 & 0.306 \\
\hline Percentage & 61.051 & 29.053 \\
\hline Cum. Percentage & 61.051 & 90.103 \\
\hline Cum.Constr.Percentage & 61.051 & 90.103 \\
\hline Spec.-env. correlations & 1.000 & 1.000 \\
\hline
\end{tabular}

\begin{tabular}{l|l|l}
\hline \multicolumn{3}{c}{ Biplot scores for env. variables } \\
\hline & Axis 1 & Axis 2 \\
\hline Depth & -0.705 & 0.232 \\
Chl-a & 0.726 & 0.191 \\
Sdep & -0.316 & 0.024 \\
DO & -0.745 & -0.281 \\
NO3 & 0.348 & 0.018 \\
\%OM & 0.572 & -0.192 \\
\%OC & 0.571 & -0.187 \\
Silt & -0.78 & -0.205 \\
\hline
\end{tabular}

Figure A11. Relationship among environmental parameters and HHVprox of submerged macrophytes in Kukud, Songkhla Lake area from May 2017 to May 2018 